\title{
AN ANALYTICAL STUDY OF TOTAL FDI INFLOW, OUTFLOW AND NET FDI OF FIVE SOUTH ASIAN COUNTRIES OVER THE PERIOD 1992-2019
}

\author{
Sushanta Kumar Tarai \\ Research Scholar \\ Department of Economics \\ Berhampur University, Odisha
}

\author{
Prof. Sudhakar Patra \\ Research Supervisor, \\ Department of Economics \\ Berhampur University, Odisha
}

Article DOI: https://doi.org/10.36713/epra6901

DOI No: 10.36713/epra6901

\begin{abstract}
This present research aims to analyze the total FDI inflow, outflow and net FDI of five South Asian countries over the period 1992-2019.This study is based on 28years Time series data taken from the World Bank Development Indicators. In order to compare the FDI inflow, outflow and net FDI inflow of India, Pakistan, Sri Lanka, Bangladesh, Nepal over the period 1992-2019,both descriptive and inferential statistical tools such as correlation test, paired t test, the familiar linear regression model, Granger-Causality test, percentage analysis and tables, are used for analysis, hypothesis testing and interpretation of data. This study used various secondary data. Economic development of the developing countries like India, Pakistan, Sri Lanka, Bangladesh, and Nepal largely rely on FDI. However, the study also reveals that in the last two decades, India received 23 times more FDI than Bangladesh, Pakistan, Sri Lanka and Nepal. For attracting more FDI, these nations require to create more congenial and favorable atmosphere towards the foreign investors. It is also concluded that the after implementing make in India campaign investing countries in total FDI inflow are increased.

KEYWORDS: FDI inflow, FDI outflow, GDP growth.
\end{abstract}

\section{INTRODUCTION}

The rapid expansion in FDI in India paves the way all over the country. Foreign Direct Investment (FDI) has played an important role in the process of globalization during the past two decades. South Asia has done very well historically in attracting foreign direct investment. It was one of the first emerging regions to welcome FDI as part of a strategy of export-led development and, as a result, its shares both of emerging market FDI inflows and of global exports grew quickly in the period of 19922019. The rapid expansion in FDI by multinational enterprises since the mid-eighties may be attributed to significant changes in technologies, greater liberalization of trade and investment regimes, and deregulation and privatization of markets in many countries including developing countries like India. Capital formation is an important determinant of economic growth. While domestic investments add to the capital stock in an economy, FDI plays a complementary role in overall capital formation and in filling the gap between domestic savings and investment.

\section{Hypothesis}

FDI inflow in India is continuously increasing than other four nations over the period from 1992-2019.

\section{Analysis Procedure}

The used data has been presented through tabular and graphical analysis to make a clear view of the five selected countries. In addition, a comparison of the ratios between the five countries for a year and for all the countries over the period of 1992 to 2019 has been made to analyze the comparative FDI inflow ratios, outflows ratios and net FDI ratios. I used a ratio analysis for comparison of the FDI inflows outflows ratios and net FDI ratios.

\section{LITERATURE REVIEW}

Jumanne and Keong (2017) ${ }^{1}$ examined the direct role played by governments of the SSA low-income countries to attract potential FDI inflows in their accountabilities as advocates of public sector 
management and institutions for poverty reduction. The study employs panel data for low-income economies over the period 2005-2015. Panel unit root tests by IPS and Fisher-ADF are applied to test for data stationary thus furthering the conduct of panel Co-integration analysis using Pedroni tests. Both tests confirm for data stationary and long-run relationships.

Gupta $(\mathbf{2 0 1 7})^{2}$ found that whether human capital plays a vital role in the distribution of foreign direct investments (FDI) across Indian states and attracts FDI to India. The results from the national level study, undertaken for the period 1975-2013 show that the improvement in human capital does not cause growth in FDI inflows, and the growth in FDI inflows does not cause improvement in human capital. The results of panel regression, undertaken for period 2000-2010 show that the differences in the endowment of human capital do not explain the variations in the distribution of FDI across the states; rather, size of the market reflected in the State Gross Domestic Product, availability of cheap labour, and infrastructure for power supply are the crucial factors affecting the FDI distribution across the states.

Bayar \& Naib (2016) ${ }^{3}$, investigated the interaction between corruption and foreign direct investment inflows in 23 emerging market economies during the period 2002-2014 by employing Wasteland-DurbinHausman (2008) co integration test. We found that control of corruption and rule of law had no statistically significant impact on attraction of foreign direct investments in overall panel.

Sharma and Dr. Singh (2016) ${ }^{4}$ elaborated FDI in India encompasses a vital role in the economic process and development of India. FDI in Asian country in numerous sectors will achieve intensification in economy through formation of jobs. In this paper the study examines the major features of FDI and also checks the impact of various economic indicators which help to pull the inflow of FDI in Indian economy. The purpose of the study is to find out the status of inflows of FDI in post and preLiberalized period. "For Indians FDI is a responsibility, it means to First Develop India, for global investors FDI is an opportunity in the form of Foreign Direct Investment. (Source: "FDI as Drivers of Growth in Economic sectors, 2015"

Dr. Rajeswari \& Akilandeswari, (2015) 5 explained that FDI has given a major boost to global integration process, by linking capital and labour markets and by raising raise wages and capital productivity in recipient countries. With newly liberalized trade and investment regimes and new technologies lowering transport and communication costs, multinational firms have evolved increasingly global strategies to capture the large savings arising from specialization and dispersion of activities. World network of multiple linkages has developed intra-firm trade across national and their affiliates in developing as well as developed countries.

\section{Research Questions}

1. Which country is attracting highest FDI inflow?

2. How much is India getting regarding FDI inflow?

\section{METHODOLOGY OF THE STUDY}

This study mainly based on secondary time series data. The data has been collected from the World Bank Indicators database over the period 1992-2019. The Time series data estimation will capture the dynamic behaviour of the parameters and will provide more efficient estimation and information of the parameters. This study is fully analysis in nature where all tables and charts are computed using EXCEL sheet.

Time Period of the Study

The data used in this study is quantitative in nature and borrowed from the World Bank development indicators data base. The data contains 28 years of data from the year 1992 to 2019 .

\section{Statistical Methods to Be Used}

This study includes statistical methods like Descriptive statistics, Mean, Standard Deviation, Correlation, Regression, etc. using MS-Excel and SPSS. And summery statistics has been used to comparison of all five nations regarding FDI inflow, outflow and net FDI.

\section{FDI in Developing Countries}

The flow of FDI to the LDC is still very thin with the exception of India and Vietnam constituting less than one percent of the global FDI inflows. About 80 percent of FDI is confined within developed countries (Bahar, H. Murtaza, M. G. 2006). This denotes that investments from developed and developing countries are heading mainly for developed countries. In fact, even investments from least developed countries, though small in volume, are also heading for developed countries. This is rather unfortunate; especially in the context that the governments of almost all the LDCs and the developing countries have been trying to attract FDI with policy formulation and other attractions.

\section{Macro-economic Reforms/Performance of South Asian Countries}

India: Economic reforms started in the early eighties, but a comprehensive liberalization and privatization process started in July 1991 in the backdrop of the balance of payment crisis and foreign exchange liquidity crisis faced by the economy. Since then, there have been attempts to integrate the Indian economy with the rest of the world in a variety of ways, i.e., the removal of quantitative restrictions, reducing tariffs and exchange rate flexibility. India launched its second-generation reforms in 2002, with a focus on reducing the fiscal deficit, improving infrastructure, reforming labor laws and energizing 
the states to participate actively in stepping up the pace of reforms. India raised its FDI limits in many important sectors including telecommunication, banking and insurance and civil aviation.

Pakistan: Though several reform measures were carried out prior to 2001, formally the economic reforms program had its genesis in the year 2001 when Pakistan signed a three years' agreement with IMF under the Poverty Reduction and Growth Facility (PRGF) program. Since its approval, seven program reviews have been completed successfully and discussions for the eighth review have been scheduled for April 2006. The key to restoring growth has been the authorities determined implementation of sound financial policies and structural reforms including tax reform, financial sector reform, investment policies including FDI policy, and enterprise reform. These policies have reduced distortions and increased efficiency, and also lifted uncertainty about the future course of economic policies.

Sri Lanka: In 1977, Sri Lanka became the first among all the South Asian economies to open up its economy to the outside world, and even to this day it remains one of the most outward oriented economies in the region. The economic reforms, from their inception, marked a sharp shift from a relatively closed economy prioritizing import substitution policies to a liberalized market and an export-oriented economy.10 Some of the major reforms were carried out in the areas of: (i) liberalization of trade policy and exchange rate system; (ii) export promotion and incentives to investment, and (iii) the rationalization of public expenditure.

Bangladesh: Major reforms were implemented as a part of structural adjustment policies under the auspices of the World Bank and the IMF in the 1980s and early 1990s. The efforts started with World Bank structural and sectoral adjustment loans (SALs and SECLs) in 1980. IMF introduced a three-year structural adjustment facility (SAF) in 1986 under which major reform initiatives were undertaken in areas such as agricultural policy, trade and industrial policy, along with privatization and public enterprise reforms, fiscal policy reform and financial sector reform. Moreover, the implementation of these reforms gained momentum during the 1990s.

Nepal: In line with changes in the development aid strategy of donors, Nepal embarked upon a new economic policy regime in the mid 1980 s. It has carried out various components of economic reform policies including fiscal, trade and FDI policies during the last decade. Quantitative restrictions on imports have been fully removed. Customs duties have been rationalized and substantially reduced. Reforms have also been executed on the foreign exchange front. However, political instability has stopped the reform process and the ambitions of the business community.

\section{FDI INFLOWS TO FIVE SOUTH ASIAN NATIONS: A COMPARATIVE ANALYSIS}

In 1992-2019 the top five FDI recipient countries of South Asia is India. Since 1992, India has also been figuring among the top five South Asian nations. India has become the first economy from South Asia, to reach the league of top five countries during the period of 1992-2019. However, in terms of share of total Asian FDI inflows, India is still much below that of China, Hong Kong and Singapore. Table 1 depicts the FDI inflows, outflows, and net FDI of India for the period of 1992 to 2019.

\section{FDI SCENARIO IN INDIA}

Table-1: FDI in India from 1992 to 2019 INDIA

\begin{tabular}{|c|c|c|c|c|c|c|}
\hline \multicolumn{7}{|c|}{ INDIA } \\
\hline Time & $\begin{array}{c}\text { FDI, N } \\
\text { (Bop, current) }\end{array}$ & $\begin{array}{c}\text { FDI, N } \\
\text { ( } \mathbf{~} \$ \text { ) }\end{array}$ & $\begin{array}{c}\text { FDI, NI } \\
\text { (Bop, current) }\end{array}$ & $\begin{array}{c}\text { FDI, } \\
\text { NI (m\$) }\end{array}$ & $\begin{array}{c}\text { FDI, NO } \\
\text { (Bop, current) }\end{array}$ & $\begin{array}{c}\text { FDI, NO } \\
\text { (m\$) }\end{array}$ \\
\hline 1992 & $-\$ 276,512,439$ & $-276.51 \mathrm{~m}$ & $\$ 276,512,439$ & $276.51 \mathrm{~m}$ & $\$ 24,000,000$ & $24.00 \mathrm{~m}$ \\
\hline 1993 & $-\$ 55,019,384$ & $-550.02 \mathrm{~m}$ & $\$ 550,370,025$ & $550.37 \mathrm{~m}$ & $\$ 350,641$ & $0.35 \mathrm{~m}$ \\
\hline 1994 & $-\$ 890,688,166$ & $-890.69 \mathrm{~m}$ & $\$ 973,271,469$ & $973.27 \mathrm{~m}$ & $\$ 82,583,303$ & $82.58 \mathrm{~m}$ \\
\hline 1995 & $-\$ 2,026,439,031$ & $-2026.44 \mathrm{~m}$ & $\$ 2,143,628,110$ & $2143.63 \mathrm{~m}$ & $\$ 117,189,079$ & $117.19 \mathrm{~m}$ \\
\hline 1996 & $-\$ 2,186,732,315$ & $-2186.73 \mathrm{~m}$ & $\$ 2,426,057,022$ & $2426.06 \mathrm{~m}$ & $\$ 2,393,247,067$ & $2393.25 \mathrm{~m}$ \\
\hline 1997 & $-\$ 3,464,411,052$ & $-3464.41 \mathrm{~m}$ & $\$ 3,577,330,042$ & $3577.33 \mathrm{~m}$ & $\$ 112,918,990$ & $112.92 \mathrm{~m}$ \\
\hline 1998 & $-\$ 2,587,058,630$ & $-2587.06 \mathrm{~m}$ & $\$ 2,634,651,658$ & $2634.65 \mathrm{~m}$ & $\$ 47,593,027$ & $47.59 \mathrm{~m}$ \\
\hline 1999 & $-\$ 2,089,233,597$ & $-2089.23 \mathrm{~m}$ & $\$ 2,168,591,054$ & $2168.59 \mathrm{~m}$ & $\$ 79,357,457$ & $79.36 \mathrm{~m}$ \\
\hline 2000 & $-\$ 3,074,684,332$ & $-3074.68 \mathrm{~m}$ & $\$ 3,584,217,307$ & $3584.22 \mathrm{~m}$ & $\$ 5,095,329,745$ & $5095.33 \mathrm{~m}$ \\
\hline 2001 & $-\$ 4,073,961,343$ & $-4073.96 \mathrm{~m}$ & $\$ 5,128,093,562$ & $5128.09 \mathrm{~m}$ & $\$ 1,054,132,218$ & $1054.13 \mathrm{~m}$ \\
\hline 2002 & $-\$ 3,947,895,992$ & $-3947.90 \mathrm{~m}$ & $\$ 5,208,967,106$ & $5208.97 \mathrm{~m}$ & $\$ 1,261,071,115$ & $1261.07 \mathrm{~m}$ \\
\hline 2003 & $-\$ 2,444,138,426$ & $-2444.14 \mathrm{~m}$ & $\$ 3,681,984,671$ & $3681.98 \mathrm{~m}$ & $\$ 1,237,846,245$ & $1237.85 \mathrm{~m}$ \\
\hline
\end{tabular}


ISSN (Online): 2455-3662

EPRA International Journal of Multidisciplinary Research (IJMR) - Peer Reviewed Journal

Volume: 7 | Issue: 4 | April 2021|| Journal DOI: 10.36713/epra2013 || SJIF Impact Factor 2021: 8.047 || ISI Value: 1.188

\begin{tabular}{|c|c|c|c|c|c|c|}
\hline 2004 & $-\$ 3,592,188,066$ & $-3592.19 \mathrm{~m}$ & $\$ 5,429,250,990$ & $5429.25 \mathrm{~m}$ & $\$ 1,837,062,923$ & $1837.06 \mathrm{~m}$ \\
\hline 2005 & $-\$ 4,628,652,265$ & $-4628.65 \mathrm{~m}$ & $\$ 7,269,407,226$ & $7269.41 \mathrm{~m}$ & $\$ 2,640,754,960$ & $2640.75 \mathrm{~m}$ \\
\hline 2006 & $-\$ 5,992,285,935$ & $-5992.29 \mathrm{~m}$ & $\$ 20,029,119,267$ & $20029.12 \mathrm{~m}$ & $\$ 14,036,833,332$ & $14036.83 \mathrm{~m}$ \\
\hline 2007 & $-\$ 8,201,628,958$ & $-8201.63 \mathrm{~m}$ & $\$ 25,227,740,887$ & $25227.74 \mathrm{~m}$ & $\$ 17,026,111,929$ & $17026.11 \mathrm{~m}$ \\
\hline 2008 & $-\$ 24,149,749,830$ & $-24149.75 \mathrm{~m}$ & $\$ 43,406,277,076$ & $43406.28 \mathrm{~m}$ & $\$ 19,256,527,246$ & $19256.53 \mathrm{~m}$ \\
\hline 2009 & $-\$ 19,485,789,183$ & $-19485.79 \mathrm{~m}$ & $\$ 35,581,372,930$ & $35581.37 \mathrm{~m}$ & $\$ 16,095,583,747$ & $16095.58 \mathrm{~m}$ \\
\hline 2010 & $-\$ 11,428,785,746$ & $-11428.79 \mathrm{~m}$ & $\$ 27,396,885,034$ & $27396.89 \mathrm{~m}$ & $\$ 15,968,099,288$ & $15968.10 \mathrm{~m}$ \\
\hline 2011 & $-\$ 23,890,659,988$ & $-23890.66 \mathrm{~m}$ & $\$ 36,498,654,598$ & $36498.65 \mathrm{~m}$ & $\$ 12,607,994,610$ & $12607.99 \mathrm{~m}$ \\
\hline 2012 & $-\$ 15,442,447,343$ & $-15442.45 \mathrm{~m}$ & $\$ 23,995,685,014$ & $23995.69 \mathrm{~m}$ & $\$ 8,553,237,671$ & $8553.24 \mathrm{~m}$ \\
\hline 2013 & $-\$ 26,388,082,470$ & $-26388.08 \mathrm{~m}$ & $\$ 28,153,031,270$ & $28153.03 \mathrm{~m}$ & $\$ 1,764,948,800$ & $1764.95 \mathrm{~m}$ \\
\hline 2014 & $-\$ 22,890,162,761$ & $-22890.16 \mathrm{~m}$ & $\$ 34,576,643,694$ & $34576.64 \mathrm{~m}$ & $\$ 11,686,480,933$ & $11686.48 \mathrm{~m}$ \\
\hline 2015 & $-\$ 36,495,216,491$ & $-36495.22 \mathrm{~m}$ & $\$ 44,009,492,130$ & $44009.49 \mathrm{~m}$ & $\$ 7,514,275,639$ & $7514.28 \mathrm{~m}$ \\
\hline 2016 & $-\$ 39,411,278,940$ & $-39411.28 \mathrm{~m}$ & $\$ 44,458,571,546$ & $44458.57 \mathrm{~m}$ & $\$ 5,047,292,606$ & $5047.29 \mathrm{~m}$ \\
\hline 2017 & $-\$ 28,875,941,053$ & $-28875.94 \mathrm{~m}$ & $\$ 39,966,091,359$ & $39966.09 \mathrm{~m}$ & $\$ 11,090,150,305$ & $11090.15 \mathrm{~m}$ \\
\hline 2018 & $-\$ 30,699,661,201$ & $-30699.66 \mathrm{~m}$ & $\$ 42,117,450,737$ & $42117.45 \mathrm{~m}$ & $\$ 11,417,789,536$ & $11417.79 \mathrm{~m}$ \\
\hline 2019 & $-\$ 38,504,400,322$ & $-38504.40 \mathrm{~m}$ & $\$ 50,605,327,354$ & $50605.33 \mathrm{~m}$ & $\$ 12,100,927,032$ & $12100.93 \mathrm{~m}$ \\
\hline Total & $-\$ 367,688,705,261$ & $-367688.71 \mathrm{~m}$ & $\$ 541,074,675,576$ & $541074.68 \mathrm{~m}$ & $\$ 180,149,689,445$ & $180149.69 \mathrm{~m}$ \\
\hline
\end{tabular}

Source: World Bank Database

In above table, that is table-1, in which the data regarding FDI inflow, outflow, and net FDI of India from 1992-2019,i.e. 28 years data are there, where it is obvious that the total net FDI in India is negative that shows that outflow is not much more than inflow, that is in number $-367688.71 \mathrm{~m}$ USD. Moreover, the total FDI inflow in 28 years of time period is $541074.68 \mathrm{~m}$ USD whereas the outflow is $180149.69 \mathrm{~m}$ USD. This is shown in graphically below with individual graph.

Figure-1: The Total FDI Inflow into India from 1992-2019

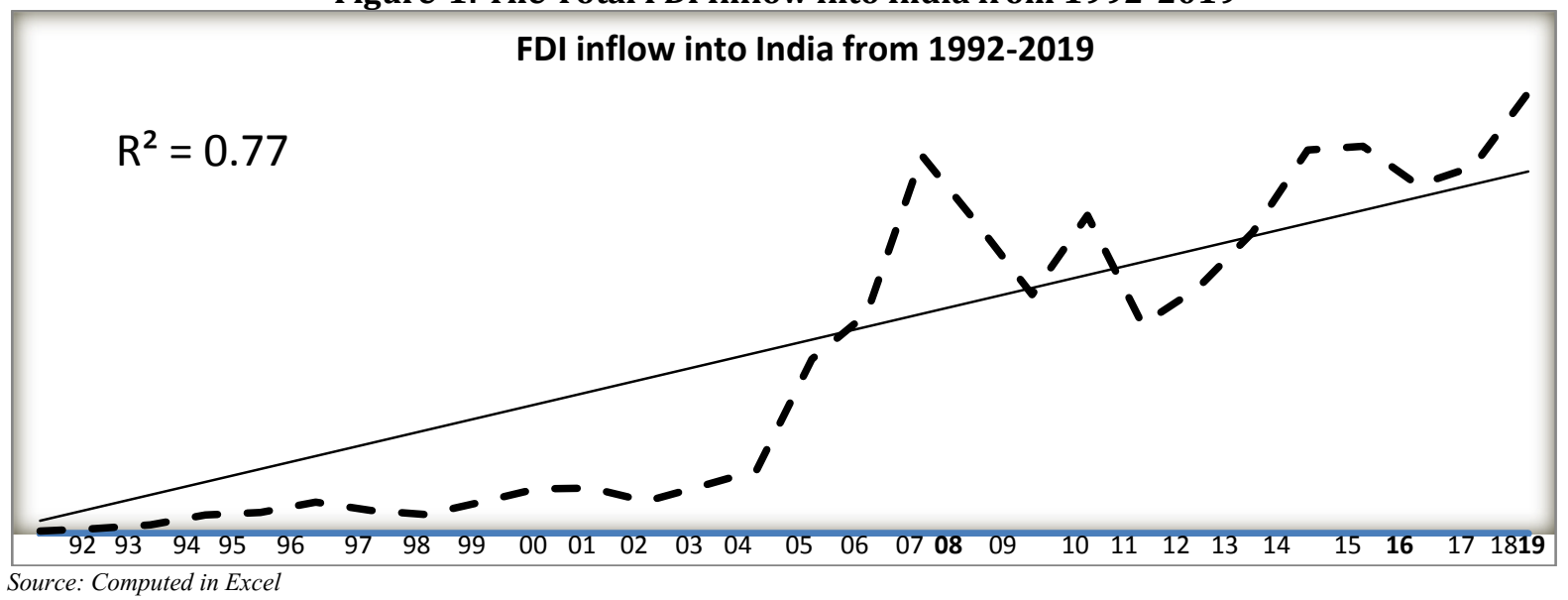

The Figure-1, thatFDI inflow into India from 19922019 , i.e. 28 years data have been shown, where one trend line has been computed which shows that the inflow of FDI into India is increasing year by year. From 1992 to 2004, it is little bit fluctuating but increasing in nature but after 2005 it has been suddenly increased up to 2008 that is from 5429.25 mUSD to $43406.28 \mathrm{~m}$ USD. Again it has been decreasing and increasing and so on. And it is highest in 2019 i.e. $50605.33 \mathrm{~m}$ USD. 
Figure-2: The Total FDI Outflow by India from 1992-2019

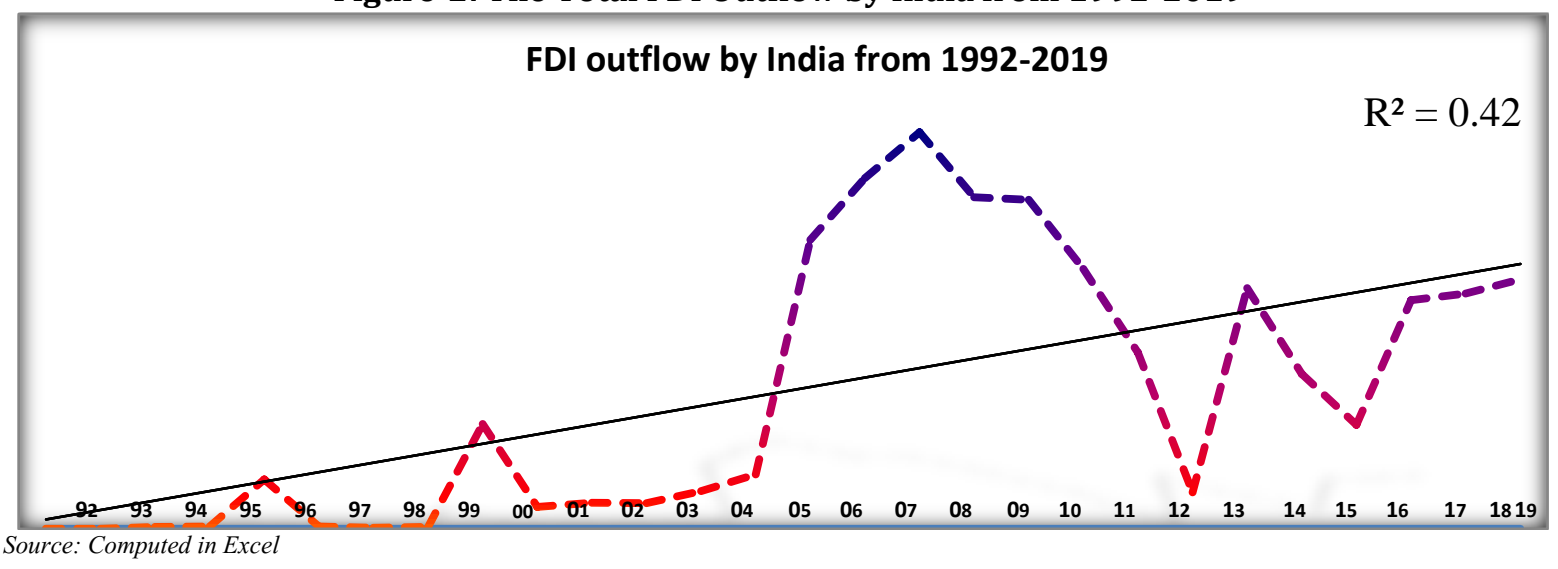

The Figure-2, that shows the FDI out flow from India from 1992-2019, where one trend line has been drawn which shows that the out flow of FDI by India is increasing slowly but after 2004 it has been increased rapidly up to 2007 i.e. from $1837.06 \mathrm{~m}$ USD to $19256.53 \mathrm{~m}$ USD. Again the slope has been decreased for one year slowly up to 2008, then for one year it is stable till 2009 , then after it has been downward rapidly up to 2012. It is then in upward then downward. Finally it is $12100.93 \mathrm{~m}$ USD in 2019. However, the FDI out flow is high in 2008, i.e. $19256.53 \mathrm{~m}$ USD.

Figure-3: The Net FDI in India from 1992-2019

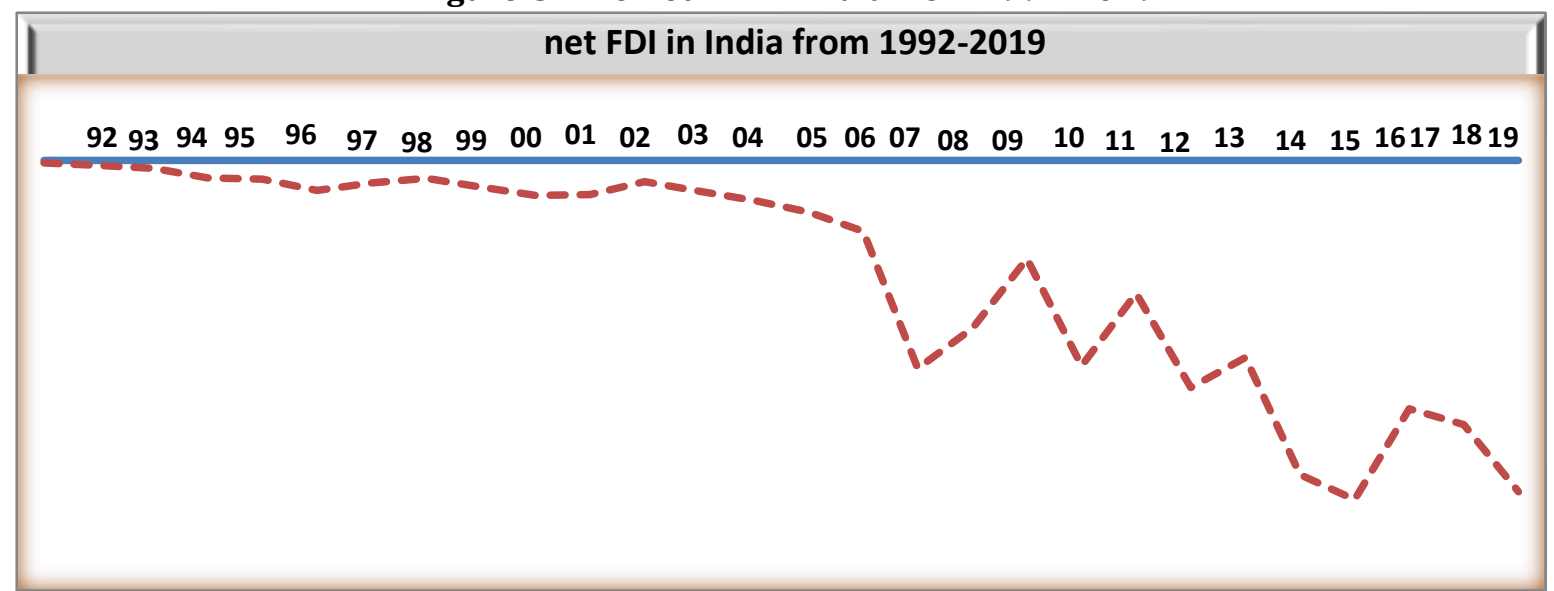

Source: Computed in Excel

The Figure-3 shows the net FDI in India from 19922019, where it is depicted that the net FDI is negative. Gradually it has been downward up to
2019, i.e. $-38504.40 \mathrm{~m}$ USD. In 2017 it is very low that is $-39411.28 \mathrm{~m}$ USD.

\section{FDI Scenario in Pakistan}

Table-2: FDI in Pakistan from 1992 to 2019

\begin{tabular}{|c|c|c|c|c|c|c|}
\hline \multicolumn{7}{|c|}{ PAKISTAN } \\
\hline Year & $\begin{array}{c}\text { FDI, N } \\
\text { (BoP, current) }\end{array}$ & $\begin{array}{c}\text { FDI, N } \\
\text { (m \$) }\end{array}$ & $\begin{array}{c}\text { FDI, NI } \\
\text { (BoP, current) }\end{array}$ & $\begin{array}{c}\text { FDI, NI } \\
\text { (m \$) }\end{array}$ & $\begin{array}{c}\text { FDI, NO } \\
\text { (BoP, current) }\end{array}$ & $\begin{array}{c}\text { FDI, NO } \\
\text { (m \$) }\end{array}$ \\
\hline 1992 & -348059754 & $-348.06 \mathrm{~m}$ & 336479857 & $336.48 \mathrm{~m}$ & -11579897 & $-11.58 \mathrm{~m}$ \\
\hline 1993 & -350710419 & $-350.71 \mathrm{~m}$ & 348556958 & $348.56 \mathrm{~m}$ & -2153461 & $-2.15 \mathrm{~m}$ \\
\hline 1994 & -420058005 & $-420.06 \mathrm{~m}$ & 421024638 & $421.02 \mathrm{~m}$ & 966634 & $0.97 \mathrm{~m}$ \\
\hline 1995 & -722221107 & $-722.22 \mathrm{~m}$ & 722631561 & $722.63 \mathrm{~m}$ & 410453 & $0.41 \mathrm{~m}$ \\
\hline 1996 & -915190761 & $-915.19 \mathrm{~m}$ & 921976183 & $921.98 \mathrm{~m}$ & 6785421 & $6.79 \mathrm{~m}$ \\
\hline 1997 & -740567596 & $-740.57 \mathrm{~m}$ & 716253125 & $716.25 \mathrm{~m}$ & -24314471 & $-24.31 \mathrm{~m}$ \\
\hline 1998 & -456000000 & $-456.00 \mathrm{~m}$ & 506000000 & $506.00 \mathrm{~m}$ & 50000000 & $50.00 \mathrm{~m}$ \\
\hline
\end{tabular}


ISSN (Online): 2455-3662

EPRA International Journal of Multidisciplinary Research (IJMR) - Peer Reviewed Journal

Volume: 7 | Issue: 4 | April 2021|| Journal DOI: 10.36713/epra2013 || SJIF Impact Factor 2021: 8.047 || ISI Value: 1.188

\begin{tabular}{|c|c|c|c|c|c|c|}
\hline 1999 & -511000000 & $-511.00 \mathrm{~m}$ & 532000000 & $532.00 \mathrm{~m}$ & 21000000 & $21.00 \mathrm{~m}$ \\
\hline 2000 & -297000000 & $-297.00 \mathrm{~m}$ & 308000000 & $308.00 \mathrm{~m}$ & 11000000 & $11.00 \mathrm{~m}$ \\
\hline 2001 & -352000000 & $-352.00 \mathrm{~m}$ & 378000000 & $378.00 \mathrm{~m}$ & 26000000 & $26.00 \mathrm{~m}$ \\
\hline 2002 & -795000000 & $-795.00 \mathrm{~m}$ & 826000000 & $826.00 \mathrm{~m}$ & 31000000 & $31.00 \mathrm{~m}$ \\
\hline 2003 & -515000000 & $-515.00 \mathrm{~m}$ & 534000000 & $534.00 \mathrm{~m}$ & 19000000 & $19.00 \mathrm{~m}$ \\
\hline 2004 & -1062000000 & $-1062.00 \mathrm{~m}$ & 1118000000 & $1118.00 \mathrm{~m}$ & 56000000 & $56.00 \mathrm{~m}$ \\
\hline 2005 & -2156000000 & $-2156.00 \mathrm{~m}$ & 2201000000 & $2201.00 \mathrm{~m}$ & 45000000 & $45.00 \mathrm{~m}$ \\
\hline 2006 & -4164000000 & $-4164.00 \mathrm{~m}$ & 4273000000 & $4273.00 \mathrm{~m}$ & 109000000 & $109.00 \mathrm{~m}$ \\
\hline 2007 & -5492000000 & $-5492.00 \mathrm{~m}$ & 5590000000 & $5590.00 \mathrm{~m}$ & 98000000 & $98.00 \mathrm{~m}$ \\
\hline 2008 & -5389000000 & $-5389.00 \mathrm{~m}$ & 5438000000 & $5438.00 \mathrm{~m}$ & 49000000 & $49.00 \mathrm{~m}$ \\
\hline 2009 & -2267000000 & $-2267.00 \mathrm{~m}$ & 2338000000 & $2338.00 \mathrm{~m}$ & 71000000 & $71.00 \mathrm{~m}$ \\
\hline 2010 & -1975000000 & $-1975.00 \mathrm{~m}$ & 2022000000 & $2022.00 \mathrm{~m}$ & 47000000 & $47.00 \mathrm{~m}$ \\
\hline 2011 & -1264000000 & $-1264.00 \mathrm{~m}$ & 1326000000 & $1326.00 \mathrm{~m}$ & 62000000 & $62.00 \mathrm{~m}$ \\
\hline 2012 & -782000000 & $-782.00 \mathrm{~m}$ & 859000000 & $859.00 \mathrm{~m}$ & 77000000 & $77.00 \mathrm{~m}$ \\
\hline 2013 & -1121000000 & $-1121.00 \mathrm{~m}$ & 1333000000 & $1333.00 \mathrm{~m}$ & 212000000 & $212.00 \mathrm{~m}$ \\
\hline 2014 & -1765000000 & $-1765.00 \mathrm{~m}$ & 1887000000 & $1887.00 \mathrm{~m}$ & 122000000 & $122.00 \mathrm{~m}$ \\
\hline 2015 & -1648000000 & $-1648.00 \mathrm{~m}$ & 1673000000 & $1673.00 \mathrm{~m}$ & 25000000 & $25.00 \mathrm{~m}$ \\
\hline 2016 & -2524000000 & $-2524.00 \mathrm{~m}$ & 2576000000 & $2576.00 \mathrm{~m}$ & 52000000 & $52.00 \mathrm{~m}$ \\
\hline 2017 & -2444000000 & $-2444.00 \mathrm{~m}$ & 2496000000 & $2496.00 \mathrm{~m}$ & 52000000 & $52.00 \mathrm{~m}$ \\
\hline 2018 & -1758000000 & $-1758.00 \mathrm{~m}$ & 1737000000 & $1737.00 \mathrm{~m}$ & -21000000 & $-21.00 \mathrm{~m}$ \\
\hline 2019 & -2225000000 & $-2225.00 \mathrm{~m}$ & 2218000000 & $2218.00 \mathrm{~m}$ & -7000000 & $-7.00 \mathrm{~m}$ \\
\hline Total & -44458807642 & $-44458.81 \mathrm{~m}$ & 45635922322 & $45635.92 \mathrm{~m}$ & 1177114679 & $1177.11 \mathrm{~m}$ \\
\hline
\end{tabular}

In above table, that is table-2, in which the data regarding FDI inflow, outflow, and net FDI of Pakistan from 1992-2019, i.e. 28 years data have been shown, where the total net FDI is in negative that is $-44458.81 \mathrm{~m}$ USD during this 28 years time period. In the mean time, the FDI inflow in to Pakistan is $45635.92 \mathrm{~m}$ USD during this 28 periods and the out flow is $1177.11 \mathrm{~m}$ USD.

Figure-4: The Total FDI Inflow into Pakistan from 1992-2019

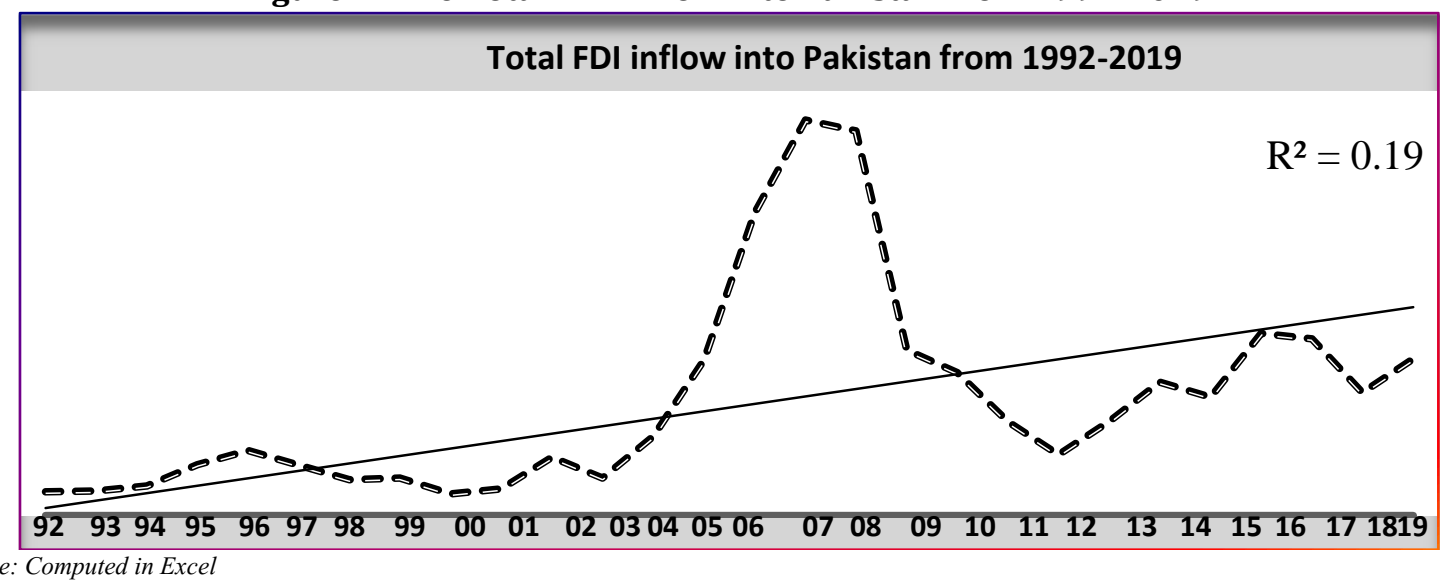

FDI inflow in to Pakistan is depicted in Figure-4, where it is shown that FDI is coming slowly from 1992 to 2003 but after this there is a record rise in FDI inflow from 2003 to 2007 that is $534 \mathrm{~m}$ USD to $5590 \mathrm{~m}$ USD. Again it has been sharply declined to around $2338 \mathrm{~m}$ USD. Then fluctuation is there in trend and in 2019 it is $2496 \mathrm{~m}$ USD. 
Figure-5: The Total FDI Outflow by Pakistan from 1992-2019

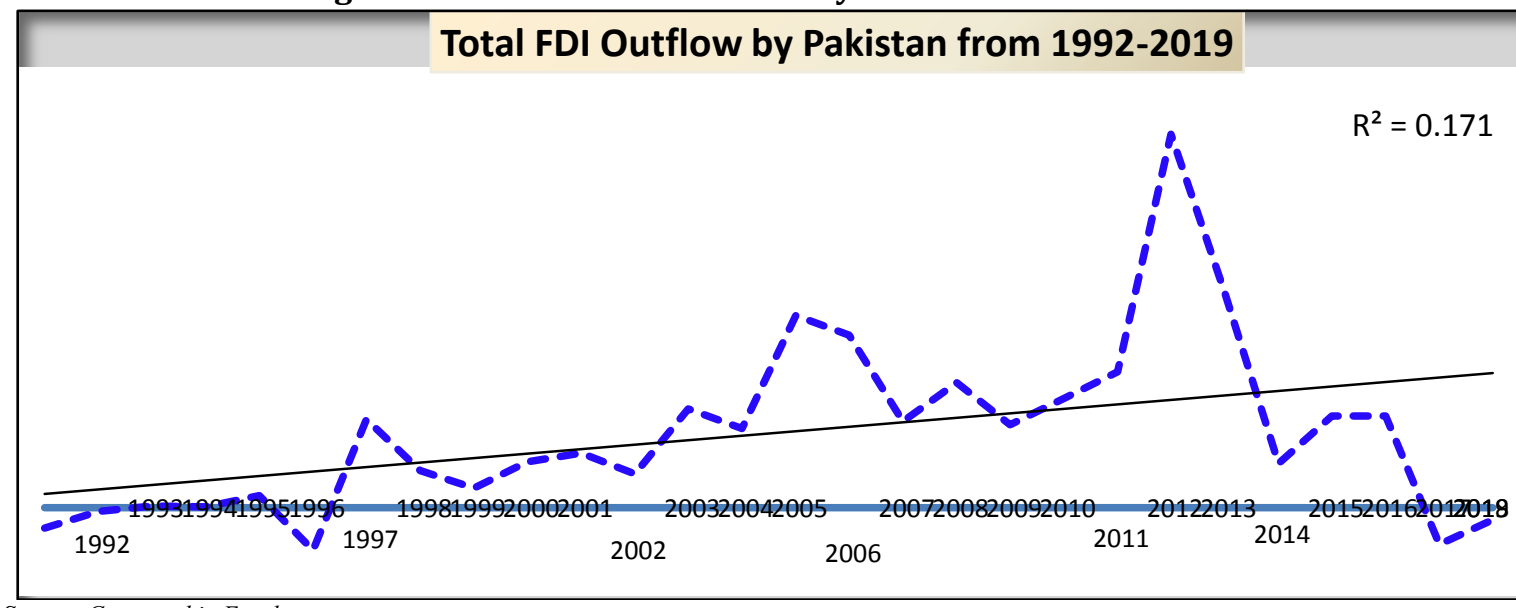

Source: Computed in Excel

In Figure-5, regarding the FDI out flow from Pakistan, initially it is negative that is $-11.58 \mathrm{~m}$ USD and after the year goes on there is increasing in out flow with little bit fluctuating and after 2011 it has been sharply inclined in trend to $212 \mathrm{~m}$ USD then sharp declining to $25 \mathrm{~m}$ USD in 2014. In 2019 it is -7 m USD.

Figure-6: The Net FDI in Pakistan from 1992-2019

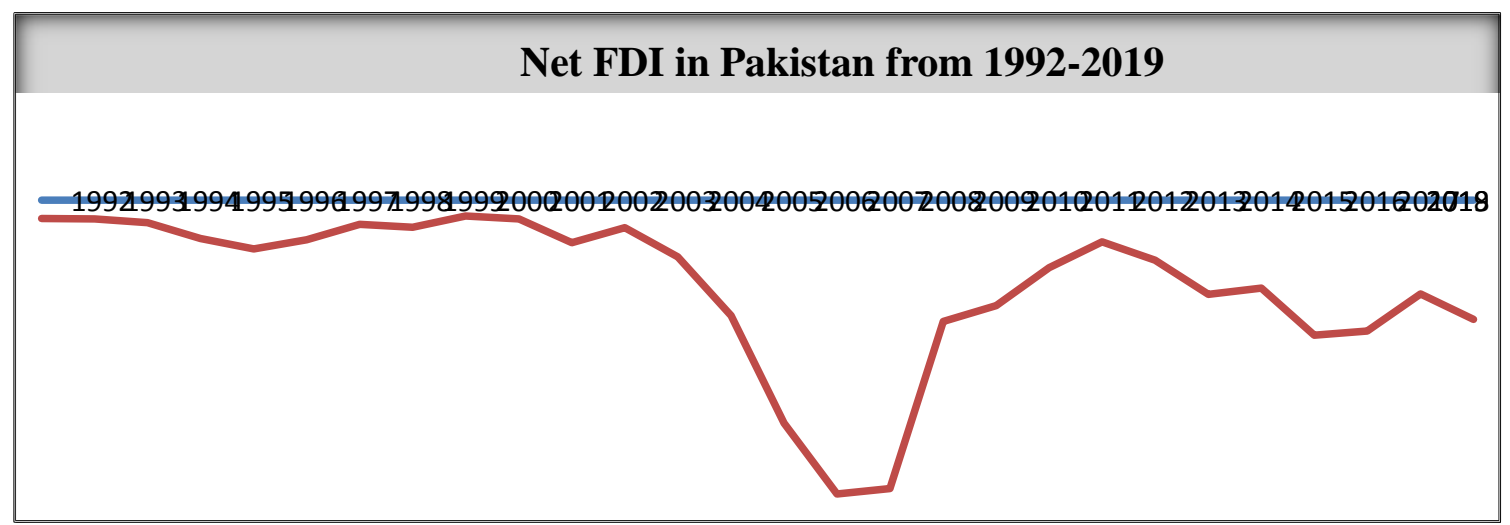

Source: Computed in Excel

In Figure-6, regarding the net FDI in Pakistan, that is totally in negative in trend. In 2006 it is $-5492 \mathrm{~m}$ USD which is very low. Then when year goes on there is little bit increasing in net FDI from $-5492 \mathrm{~m}$ USD to $-782 \mathrm{~m} \mathrm{USD}$ in 2012 . And in 2019 it is -2225 $\mathrm{m}$ USD.

FDI Scenario in Sri Lanka

Table -3: FDI in Sri Lanka from 1992 to 2019

\begin{tabular}{|c|c|c|c|c|c|c|}
\hline \multicolumn{7}{|c|}{ SRI LANKA } \\
\hline Year & $\begin{array}{c}\text { FDI, N } \\
\text { (BoP, } \\
\text { current) }\end{array}$ & $\begin{array}{c}\text { FDI, N } \\
\mathbf{( m ~ \$ ) ~}\end{array}$ & $\begin{array}{c}\text { FDI, NI } \\
\text { (BoP, current) }\end{array}$ & $\begin{array}{c}\text { FDI, NI } \\
\text { (m \$) }\end{array}$ & $\begin{array}{c}\text { FDI, NO } \\
\text { (BoP, } \\
\text { current) }\end{array}$ & $\begin{array}{c}\text { FDI, NO } \\
\text { (m \$) }\end{array}$ \\
\hline 1992 & 0 & 0 & 0 & 0 & 0 & 0 \\
\hline 1993 & -121000439 & $-121.00 \mathrm{~m}$ & 122625843 & $122.63 \mathrm{~m}$ & 1625405 & $1.63 \mathrm{~m}$ \\
\hline 1994 & -187581304 & $-187.58 \mathrm{~m}$ & 194479070 & $194.48 \mathrm{~m}$ & 6897767 & $6.90 \mathrm{~m}$ \\
\hline 1995 & -158157932 & $-158.16 \mathrm{~m}$ & 166412940 & $166.41 \mathrm{~m}$ & 8255008 & $8.26 \mathrm{~m}$ \\
\hline 1996 & -55995588 & $-56.00 \mathrm{~m}$ & 55995588 & $56.00 \mathrm{~m}$ & 5596667 & $5.60 \mathrm{~m}$ \\
\hline
\end{tabular}


ISSN (Online): 2455-3662

EPRA International Journal of Multidisciplinary Research (IJMR) - Peer Reviewed Journal

Volume: 7 | Issue: 4 | April 2021|| Journal DOI: 10.36713/epra2013 || SJIF Impact Factor 2021: 8.047 || ISI Value: 1.188

\begin{tabular}{|c|c|c|c|c|c|c|}
\hline 1997 & -119874350 & $-119.87 m$ & 119874350 & $119.87 \mathrm{~m}$ & 6918889 & $6.92 \mathrm{~m}$ \\
\hline 1998 & -430056152 & $-430.06 \mathrm{~m}$ & 430056152 & $430.06 \mathrm{~m}$ & 5000000 & $5.00 \mathrm{~m}$ \\
\hline 1999 & -193424024 & $-193.42 m$ & 193424023 & $193.42 \mathrm{~m}$ & 13000000 & $13.00 \mathrm{~m}$ \\
\hline 2000 & -176410171 & $-176.41 \mathrm{~m}$ & 176410171 & $176.41 \mathrm{~m}$ & 24000000 & $24.00 \mathrm{~m}$ \\
\hline 2001 & -172941410 & $-172.94 m$ & 172941410 & $172.94 \mathrm{~m}$ & 2000000 & $2.00 \mathrm{~m}$ \\
\hline 2002 & -171790000 & $-171.79 m$ & 171790000 & $171.79 \mathrm{~m}$ & 1000 & $0.00 \mathrm{~m}$ \\
\hline 2003 & -185050000 & $-185.05 m$ & 196500000 & $196.50 \mathrm{~m}$ & 11450000 & $11.45 \mathrm{~m}$ \\
\hline 2004 & -201410000 & $-201.41 m$ & 228720000 & $228.72 \mathrm{~m}$ & 27310000 & $27.31 \mathrm{~m}$ \\
\hline 2005 & -227010000 & $-227.01 \mathrm{~m}$ & 232800000 & $232.80 \mathrm{~m}$ & 5790000 & $5.79 \mathrm{~m}$ \\
\hline 2006 & -234000000 & $-234.00 \mathrm{~m}$ & 272400000 & $272.40 \mathrm{~m}$ & 38400000 & $38.40 \mathrm{~m}$ \\
\hline 2007 & -450400000 & $-450.40 \mathrm{~m}$ & 479700000 & $479.70 \mathrm{~m}$ & 29300000 & $29.30 \mathrm{~m}$ \\
\hline 2008 & -548000000 & $-548.00 \mathrm{~m}$ & 603000000 & $603.00 \mathrm{~m}$ & 55000000 & $55.00 \mathrm{~m}$ \\
\hline 2009 & -690500000 & $-690.50 m$ & 752200000 & $752.20 \mathrm{~m}$ & 61700000 & $61.70 \mathrm{~m}$ \\
\hline 2010 & -384000000 & $-384.00 \mathrm{~m}$ & 404000000 & $404.00 \mathrm{~m}$ & 20000000 & $20.00 \mathrm{~m}$ \\
\hline 2011 & -435059000 & $-435.06 \mathrm{~m}$ & 477559000 & $477.56 \mathrm{~m}$ & 42500000 & $42.50 \mathrm{~m}$ \\
\hline 2012 & -895920000 & $-895.92 m$ & 955920000 & $955.92 \mathrm{~m}$ & 60000000 & $60.00 \mathrm{~m}$ \\
\hline 2013 & -877190943 & $-877.19 m$ & 941116591 & $941.12 \mathrm{~m}$ & 63925648.5 & $63.93 \mathrm{~m}$ \\
\hline 2014 & -867477988 & $-867.48 m$ & 932551317 & $932.55 \mathrm{~m}$ & 65073329.77 & $65.07 \mathrm{~m}$ \\
\hline 2015 & -826805651 & $-826.81 \mathrm{~m}$ & 893628980 & $893.63 \mathrm{~m}$ & 66823329.77 & $66.82 \mathrm{~m}$ \\
\hline 2016 & -626668320 & $-626.67 m$ & 679655644 & $679.66 \mathrm{~m}$ & 52987324.45 & $52.99 \mathrm{~m}$ \\
\hline 2017 & -660241239 & $-660.24 m$ & 897049376 & $897.05 \mathrm{~m}$ & 236808136.8 & $236.81 \mathrm{~m}$ \\
\hline 2018 & -1300931667 & $-1300.93 m$ & 1372723043 & $1372.72 \mathrm{~m}$ & 71791375.69 & $71.79 \mathrm{~m}$ \\
\hline 2019 & -1542687404 & $-1542.69 m$ & 1610543974 & $1610.54 \mathrm{~m}$ & 67856570.54 & $67.86 \mathrm{~m}$ \\
\hline Total & -12740583582 & $-12740.58 m$ & 13734077472 & $13734.08 \mathrm{~m}$ & 1050010451 & $1050.01 \mathrm{~m}$ \\
\hline
\end{tabular}

In above table, that is table- 3 , in which the data regarding FDI inflow, outflow, and net FDI of Sri Lanka from 1992-2019, i.e. 28 years data have been shown, where the total net FDI is in negative that is - 12740.58m USD during this 28 years time period. In the mean time, the FDI inflow in to Sri Lanka is $13734.08 \mathrm{~m}$ USD during this 28 periods and the out flow is $1050.01 \mathrm{~m}$ USD.

Figure-7: The Total FDI Inflow into Sri Lanka from 1992-2019

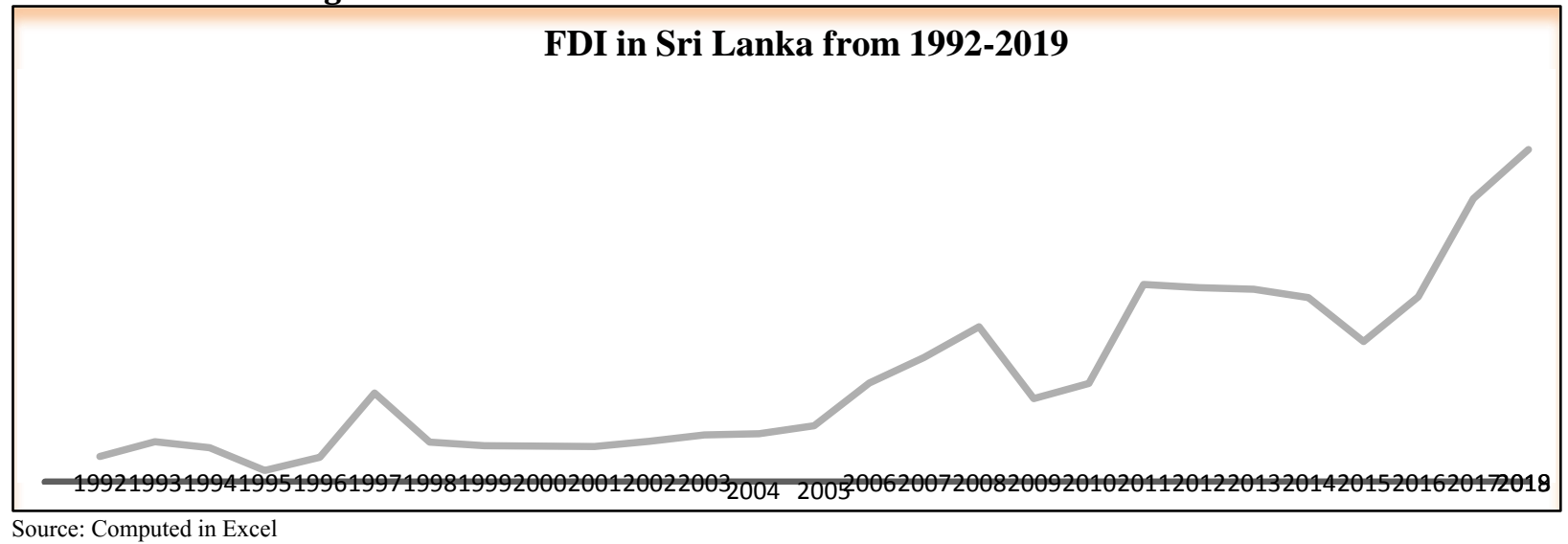

The Figure-7, that FDI inflow into Sri Lanka from 1992-2019, i.e. 28 years data have been shown, where one trend line has been computed which shows that the inflow of FDI into Sri Lanka is increasing year by year. From 1998 to 2005, it is constantly increasing but in slow rate after 2005 it has been 
suddenly increased up to 2008 that is from 232.80 mUSD to $752.20 \mathrm{~m}$ USD. Again it has been decreasing and increasing and so on. And it is highest in 2019 i.e. $1610.54 \mathrm{~m}$ USD.

Figure-8: The Total FDI Outflow by Sri Lanka from 1992-2019

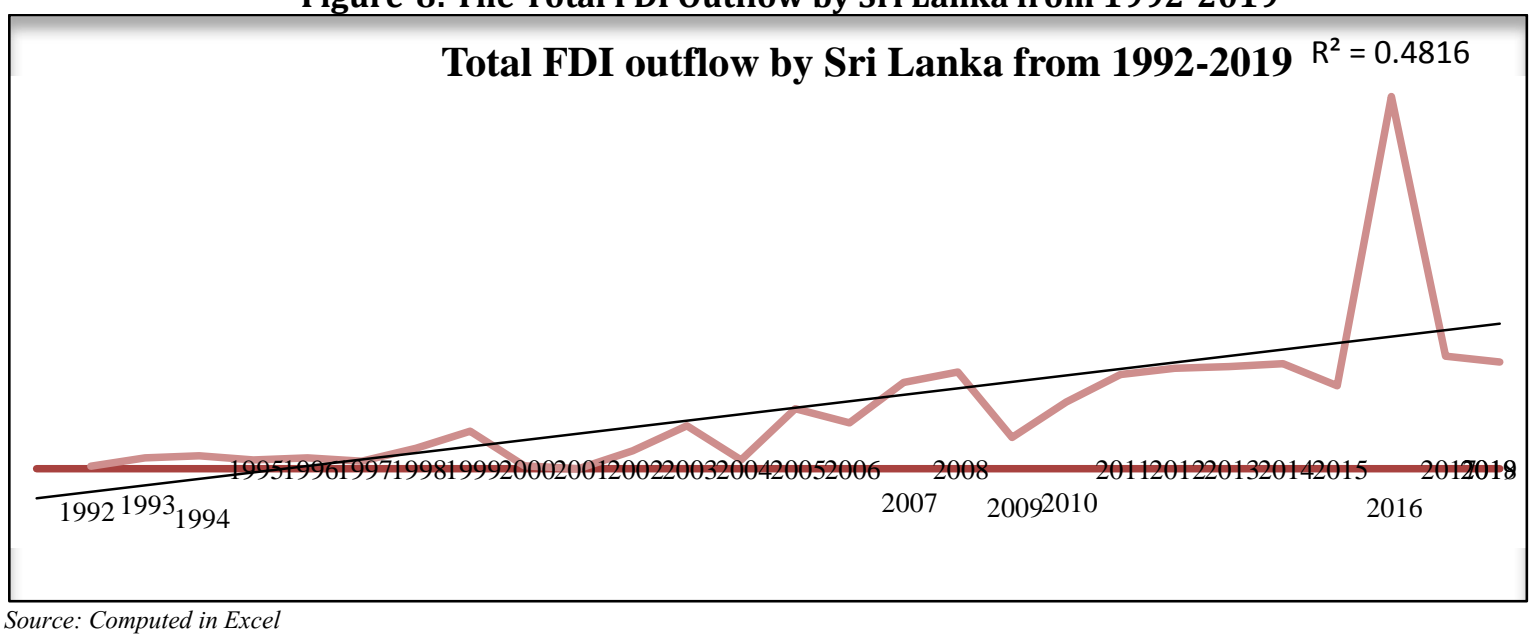

The Figure-8, that shows the FDI out flow from Sri Lanka from 1992-2019, where one trend line has been drawn which shows that the out flow of FDI by Sri Lanka is increasing slowly but after 2014 it has been increased rapidly up to 2017. Again the slope has been decreased for one year slowly up to 2018 . Finally it is $67.86 \mathrm{~m}$ USD in 2019. However, the FDI out flow is high in 2016, i.e. $236.81 \mathrm{~m}$ USD.

Figure- 9: The Net FDI in Sri Lanka from 1992-2019

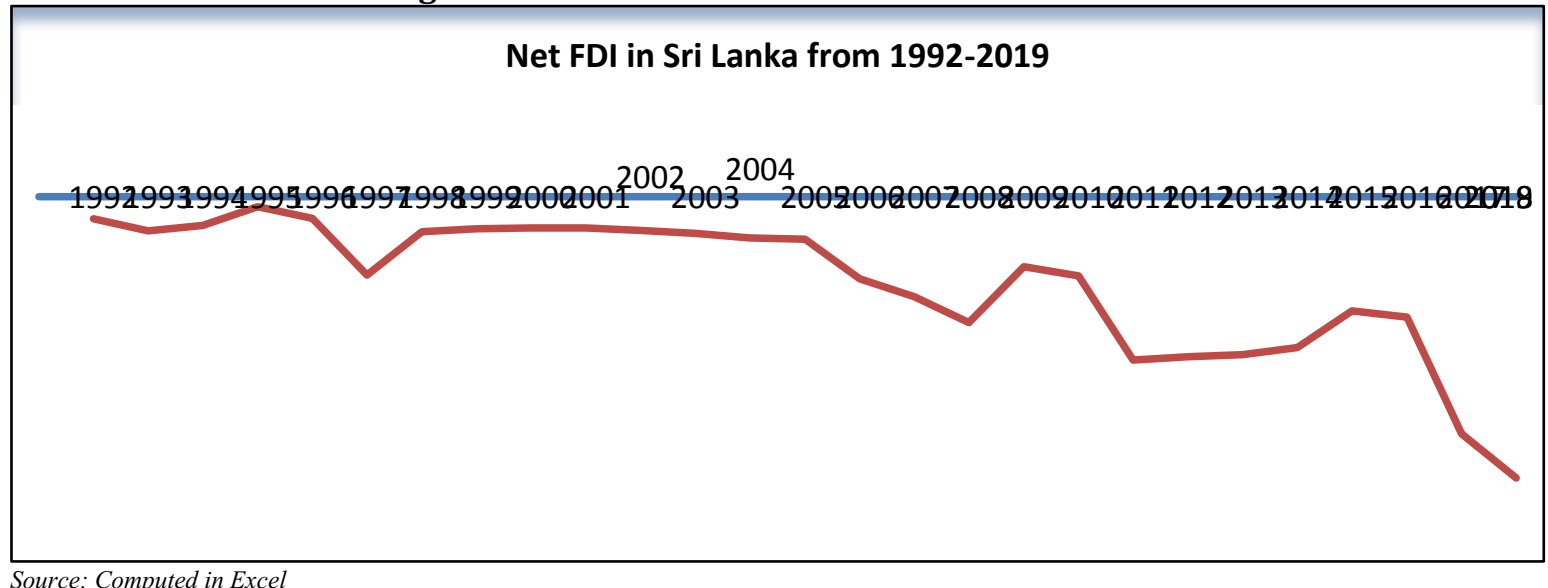

In Figure-9, regarding the net FDI in Sri Lanka, that is totally in negative in trend. In 2019 it is very low that is USD $-1542.69 \mathrm{~m}$.

\section{FDI Scenario in Bangladesh}

Table 4: FDI in Bangladesh from 1992 to 2019

\begin{tabular}{|c|c|c|c|c|c|c|}
\hline \multicolumn{7}{|c|}{ BANGLADESH } \\
\hline Year & $\begin{array}{c}\text { FDI, N } \\
\text { (Bop, current) }\end{array}$ & $\begin{array}{c}\text { FDI, N } \\
\text { ( m \$ ) }\end{array}$ & $\begin{array}{c}\text { FDI, NI } \\
\text { (Bop, current) }\end{array}$ & $\begin{array}{c}\text { FDI, NI } \\
\text { (m \$) }\end{array}$ & $\begin{array}{c}\text { FDI, NO } \\
\text { (Bop, current) }\end{array}$ & $\begin{array}{c}\text { FDI, NO } \\
\text { (m \$) }\end{array}$ \\
\hline 1992 & -3721853.382 & $-3.72 \mathrm{~m}$ & 3721853.382 & $3.72 \mathrm{~m}$ & 100000 & $0.10 \mathrm{~m}$ \\
\hline 1993 & -14049886.52 & $-14.05 \mathrm{~m}$ & 14049886.52 & $14.05 \mathrm{~m}$ & 200000 & $0.20 \mathrm{~m}$ \\
\hline 1994 & -11147788.33 & $-11.15 \mathrm{~m}$ & 11147788.33 & $11.15 \mathrm{~m}$ & 200000 & $0.20 \mathrm{~m}$ \\
\hline 1995 & -1896372.127 & $-1.90 \mathrm{~m}$ & 1896372.127 & $1.90 \mathrm{~m}$ & 1700000 & $1.70 \mathrm{~m}$ \\
\hline 1996 & -13529831.54 & $-13.53 \mathrm{~m}$ & 13529831.54 & $13.53 \mathrm{~m}$ & 12500000 & $12.50 \mathrm{~m}$ \\
\hline 1997 & -136310534.1 & $-136.31 \mathrm{~m}$ & 139376153.1 & $139.38 \mathrm{~m}$ & 3065618.981 & $3.07 \mathrm{~m}$ \\
\hline
\end{tabular}


ISSN (Online): 2455-3662

EPRA International Journal of Multidisciplinary Research (IJMR) - Peer Reviewed Journal

Volume: 7 | Issue: 4 | April 2021|| Journal DOI: 10.36713/epra2013 || SJIF Impact Factor 2021: 8.047 || ISI Value: 1.188

\begin{tabular}{|c|c|c|c|c|c|c|}
\hline 1998 & -187057212.5 & $-187.06 \mathrm{~m}$ & 190059373 & $190.06 \mathrm{~m}$ & 3002160.476 & $3.00 \mathrm{~m}$ \\
\hline 1999 & -179603006.3 & $-179.60 \mathrm{~m}$ & 179603006.3 & $179.60 \mathrm{~m}$ & 59964 & $0.06 \mathrm{~m}$ \\
\hline 2000 & -280384629.7 & $-280.38 \mathrm{~m}$ & 280384629.7 & $280.38 \mathrm{~m}$ & 2000000 & $2.00 \mathrm{~m}$ \\
\hline 2001 & -78527040.08 & $-78.53 \mathrm{~m}$ & 78527040.08 & $78.53 \mathrm{~m}$ & 20600000 & $20.60 \mathrm{~m}$ \\
\hline 2002 & -49662443.99 & $-49.66 \mathrm{~m}$ & 52304931.04 & $52.30 \mathrm{~m}$ & 2642487.047 & $2.64 \mathrm{~m}$ \\
\hline 2003 & -265507414.1 & $-265.51 \mathrm{~m}$ & 268285231.8 & $268.29 \mathrm{~m}$ & 2777817.74 & $2.78 \mathrm{~m}$ \\
\hline 2004 & -444836578 & $-444.84 \mathrm{~m}$ & 448905400.7 & $448.91 \mathrm{~m}$ & 4068822.751 & $4.07 \mathrm{~m}$ \\
\hline 2005 & -811382056.1 & $-811.38 \mathrm{~m}$ & 813321971.9 & $813.32 \mathrm{~m}$ & 1939915.771 & $1.94 \mathrm{~m}$ \\
\hline 2006 & -452928348.1 & $-452.93 \mathrm{~m}$ & 456523167.7 & $456.52 \mathrm{~m}$ & 3594819.617 & $3.59 \mathrm{~m}$ \\
\hline 2007 & -516766232.5 & $-516.77 \mathrm{~m}$ & 651029738.1 & $651.03 \mathrm{~m}$ & 134263505.5 & $134.26 \mathrm{~m}$ \\
\hline 2008 & -1137762261 & $-1137.76 \mathrm{~m}$ & 1328422987 & $1328.42 \mathrm{~m}$ & 190660725.3 & $190.66 \mathrm{~m}$ \\
\hline 2009 & -720457353.6 & $-720.46 \mathrm{~m}$ & 901286583.1 & $901.29 \mathrm{~m}$ & 180829229.6 & $180.83 \mathrm{~m}$ \\
\hline 2010 & -1165816161 & $-1165.82 \mathrm{~m}$ & 1232258247 & $1232.26 \mathrm{~m}$ & 66442085.51 & $66.44 \mathrm{~m}$ \\
\hline 2011 & -967290773.5 & $-967.29 \mathrm{~m}$ & 1264725163 & $1264.73 \mathrm{~m}$ & 297434389.8 & $297.43 \mathrm{~m}$ \\
\hline 2012 & -1295344530 & $-1295.34 \mathrm{~m}$ & 1584403460 & $1584.40 \mathrm{~m}$ & 289058929.5 & $289.06 \mathrm{~m}$ \\
\hline 2013 & -2056085293 & $-2056.09 \mathrm{~m}$ & 2602962095 & $2602.96 \mathrm{~m}$ & 546876802.6 & $546.88 \mathrm{~m}$ \\
\hline 2014 & -2497421016 & $-2497.42 \mathrm{~m}$ & 2539190940 & $2539.19 \mathrm{~m}$ & 41769923.69 & $41.77 \mathrm{~m}$ \\
\hline 2015 & -2771250741 & $-2771.25 \mathrm{~m}$ & 2831152765 & $2831.15 \mathrm{~m}$ & 59902023.75 & $59.90 \mathrm{~m}$ \\
\hline 2016 & -2292208318 & $-2292.21 \mathrm{~m}$ & 2332724781 & $2332.72 \mathrm{~m}$ & 40516462.34 & $40.52 \mathrm{~m}$ \\
\hline 2017 & -1683653529 & $-1683.65 \mathrm{~m}$ & 1810395804 & $1810.40 \mathrm{~m}$ & 126742274.7 & $126.74 \mathrm{~m}$ \\
\hline 2018 & -2924997078 & $-2925.00 \mathrm{~m}$ & 2940222420 & $2940.22 \mathrm{~m}$ & 15225341.73 & $15.23 \mathrm{~m}$ \\
\hline 2019 & -1597937389 & $-1597.94 \mathrm{~m}$ & 1596754107 & $1596.75 \mathrm{~m}$ & -1183281.155 & $-1.18 \mathrm{~m}$ \\
\hline Total & -24557535671 & $-24557.54 \mathrm{~m}$ & 26567165727 & $26567.17 \mathrm{~m}$ & 2046990019 & $2046.99 \mathrm{~m}$ \\
\hline
\end{tabular}

In above table, that is table- 4 , in which the data regarding FDI inflow, outflow, and net FDI of Bangladesh from 1992-2019, i.e. 28 years data have been shown, where the total net FDI is in negative that is $-24557.54 \mathrm{~m}$ USD during this 28 years time period. Whereas, the FDI inflow in to Bangladesh is $26567.17 \mathrm{~m}$ USD during this 28 periods and the out flow is $2046.99 \mathrm{~m}$ USD.

Figure-10: The Total FDI Inflow into Bangladesh from 1992-2019

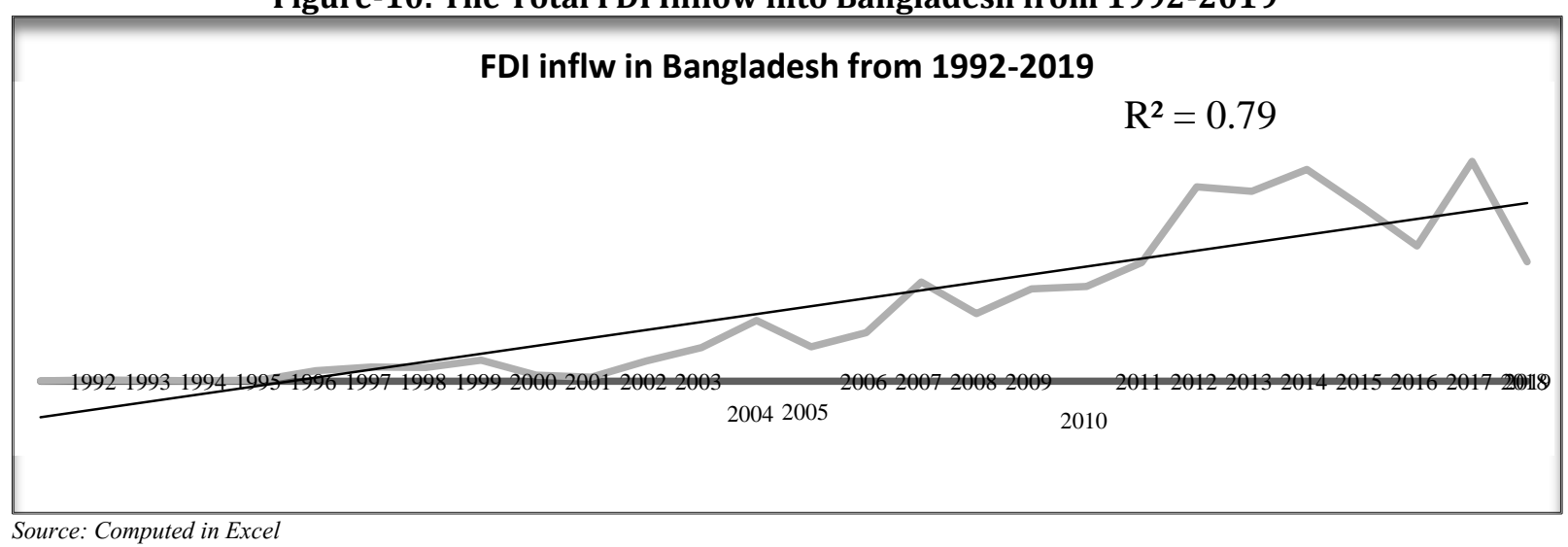

The Figure-10, that FDI inflow into Bangladesh from 1992-2019, i.e. 28 years data have been shown, where one trend line has been computed which shows that the inflow of FDI into Bangladesh is increasing year by year but in decreasing rate. From 1992 to 1995 , it is constantly increasing but in slow rate after
2003 it has been increased then decreased and so on up to 2014. Again it has been decreasing and increasing and so on. And 2017 onwards it has been decreased from USD $2940 \mathrm{~m}$ to $1596 \mathrm{~m}$ USD in 2019. 
Figure- 11: The Total FDI Outflow by Bangladesh from 1992-2019

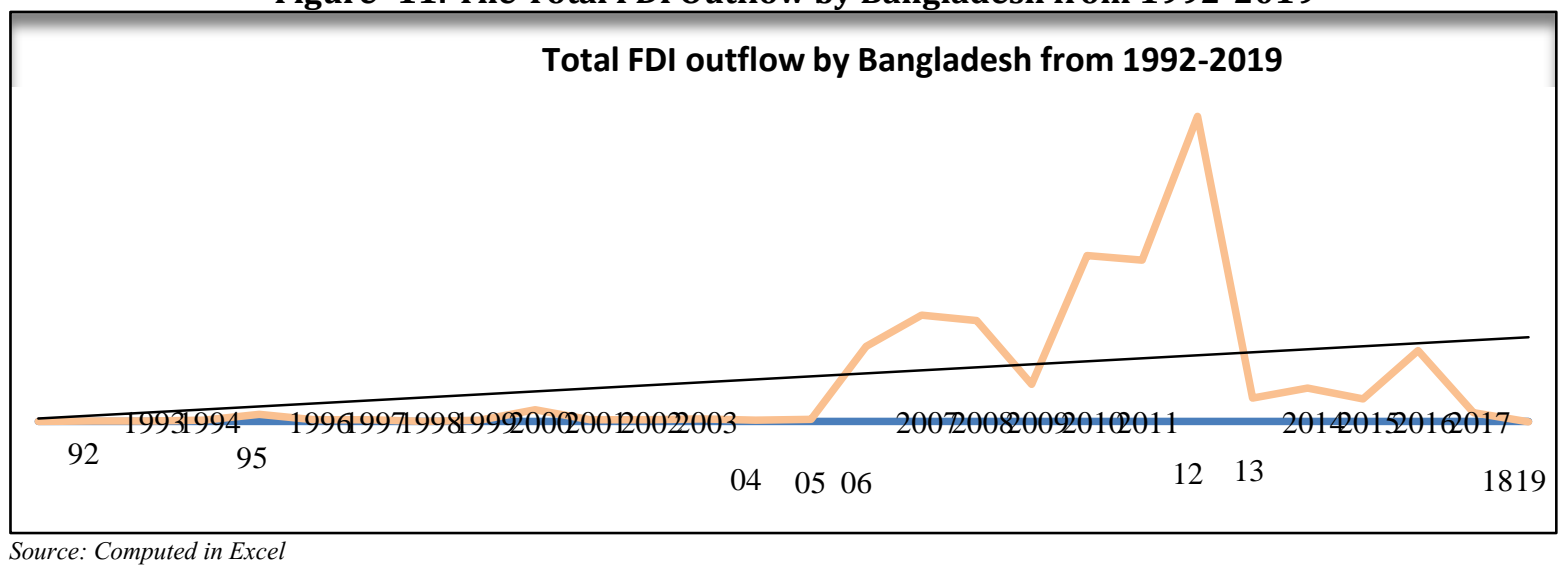

The Figure-11, that shows the FDI out flow from Bangladesh from 1992-2019, where one trend line has been drawn which shows that the out flow of FDI by Bangladeshis increasing with slow rate up to
2005. And it is increased till 2012.However; a sharp decline appeared after 2012that is from $546.88 \mathrm{~m}$ USD to $41.77 \mathrm{~m}$ USD.

Figure-12: The Net FDI in Bangladesh from 1992-2019

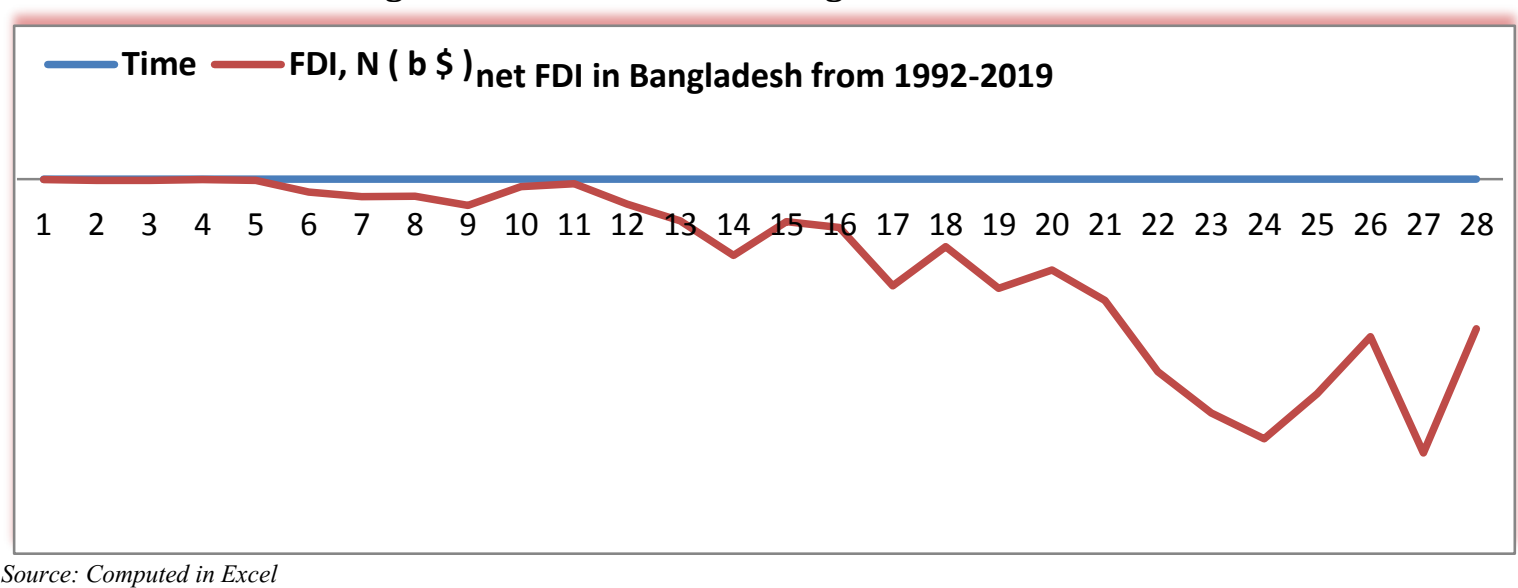

In Figure-12, regarding the net FDI in Bangladesh, that is totally in negative in trend. In 2017 it is $2925.00 \mathrm{~m}$ USD which is very low.

FDI Scenario in Nepal

Table -5: FDI in Nepal from 1992 to 2019

\begin{tabular}{|c|c|c|c|c|c|c|}
\hline \multicolumn{7}{|c|}{ NEPAL } \\
\hline Year & $\begin{array}{c}\text { FDI, N } \\
\text { (Bop, current) }\end{array}$ & $\begin{array}{c}\text { FDI, N } \\
\text { ( m \$) }\end{array}$ & $\begin{array}{c}\text { FDI, NI } \\
\text { (Bop, current) }\end{array}$ & $\begin{array}{c}\text { FDI, NI } \\
\text { (m \$) }\end{array}$ & $\begin{array}{c}\text { FDI, NO } \\
\text { (Bop, } \\
\text { current) }\end{array}$ & $\begin{array}{c}\text { FDI, NO } \\
\text { (m \$) }\end{array}$ \\
\hline 1992 & 0 & 0 & 0 & 0 & 0 & 0 \\
\hline 1993 & 0 & 0 & 0 & $0.00 \mathrm{M}$ & 0 & 0 \\
\hline 1994 & 0 & 0 & 0 & $0.00 \mathrm{M}$ & 0 & 0 \\
\hline 1995 & 0 & 0 & 0 & $0.00 \mathrm{M}$ & 0 & 0 \\
\hline 1996 & 0 & 0 & 0 & $0.00 \mathrm{M}$ & 0 & 0 \\
\hline 1997 & -19160171.09 & $-19.16 \mathrm{M}$ & 19160171.09 & $19.16 \mathrm{M}$ & 0 & 0 \\
\hline 1998 & -23056467.77 & $-23.06 \mathrm{M}$ & 23056467.77 & $23.06 \mathrm{M}$ & 0 & 0 \\
\hline 1999 & -12024659.9 & $-12.02 \mathrm{M}$ & 12024659.9 & $12.02 \mathrm{M}$ & 0 & 0 \\
\hline 2000 & -4351068.682 & $-4.35 \mathrm{M}$ & 4351068.682 & $4.35 \mathrm{M}$ & 0 & 0 \\
\hline
\end{tabular}


ISSN (Online): 2455-3662

EPRA International Journal of Multidisciplinary Research (IJMR) - Peer Reviewed Journal

Volume: 7 | Issue: 4 | April 2021|| Journal DOI: 10.36713/epra2013 || SJIF Impact Factor 2021: 8.047 || ISI Value: 1.188

\begin{tabular}{|l|c|c|c|c|c|c|}
\hline 2001 & 484826.7123 & $0.48 \mathrm{M}$ & -484826.7123 & $-0.48 \mathrm{M}$ & 0 & 0 \\
\hline 2002 & 0 & 0 & 20850000 & $20.85 \mathrm{M}$ & 0 & 0 \\
\hline 2003 & 5952541.127 & $5.95 \mathrm{M}$ & -5952541.127 & $-5.95 \mathrm{M}$ & 0 & 0 \\
\hline 2004 & -14778085.61 & $-14.78 \mathrm{M}$ & 14778085.61 & $14.78 \mathrm{M}$ & 0 & 0 \\
\hline 2005 & 417346.3839 & $0.42 \mathrm{M}$ & -417346.3839 & $-0.42 \mathrm{M}$ & 0 & 0 \\
\hline 2006 & -2451784.707 & $-2.45 \mathrm{M}$ & 2451784.707 & $2.45 \mathrm{M}$ & 0 & 0 \\
\hline 2007 & 6647983.904 & $6.65 \mathrm{M}$ & -6647983.904 & $-6.65 \mathrm{M}$ & 0 & 0 \\
\hline 2008 & -5741706.053 & $-5.74 \mathrm{M}$ & 5741706.053 & $5.74 \mathrm{M}$ & 0 & 0 \\
\hline 2009 & -995123.9307 & $-1.00 \mathrm{M}$ & 995123.9307 & $1.00 \mathrm{M}$ & 0 & 0 \\
\hline 2010 & -38271269.97 & $-38.27 \mathrm{M}$ & 38271269.97 & $38.27 \mathrm{M}$ & 0 & 0 \\
\hline 2011 & -87741711.63 & $-87.74 \mathrm{M}$ & 87741711.63 & $87.74 \mathrm{M}$ & 0 & 0 \\
\hline 2012 & -94022157.12 & $-94.02 \mathrm{M}$ & 94022157.12 & $94.02 \mathrm{M}$ & 0 & 0 \\
\hline 2013 & -91954196.1 & $-91.95 \mathrm{M}$ & 91954196.1 & $91.95 \mathrm{M}$ & 0 & 0 \\
\hline 2014 & -74179632.61 & $-74.18 \mathrm{M}$ & 74179632.61 & $74.18 \mathrm{M}$ & 0 & 0 \\
\hline 2015 & -30402676.78 & $-30.40 \mathrm{M}$ & 30402676.78 & $30.40 \mathrm{M}$ & 0 & 0 \\
\hline 2016 & -51895699.93 & $-51.90 \mathrm{M}$ & 51895699.93 & $51.90 \mathrm{M}$ & 0 & 0 \\
\hline 2017 & -105996375.6 & $-106.00 \mathrm{M}$ & 105996375.6 & $106.00 \mathrm{M}$ & 0 & 0 \\
\hline 2018 & -196265098.6 & $-196.27 \mathrm{M}$ & 196265098.6 & $196.27 \mathrm{M}$ & 0 & 0 \\
\hline 2019 & -68186670.75 & $-68.19 \mathrm{M}$ & 68186670.75 & $68.19 \mathrm{M}$ & 0 & 0 \\
\hline Total & -1815943717 & $20.85 \mathrm{M}$ & 928821858.7 & $928.82 \mathrm{M}$ & 0 & 0 \\
\hline Soln
\end{tabular}

Source: World Bank Database

In above table, that is table-5, in which the data regarding FDI inflow, outflow, and net FDI of Nepal from 1992-2019, i.e. 28 years data have been shown, where the total net FDI is $20.85 \mathrm{~m}$ USD during this 28 years time period. And the FDI inflow into Nepal is $928.82 \mathrm{~m}$ USD during this 28 years and the outflow is nil during 28 years. It means Nepal never investing in any countries due to low capital in the country.

Figure-13: The Total FDI Inflow into Nepal from 1992-2019

\section{FDI in Nepal from 1992-2019}

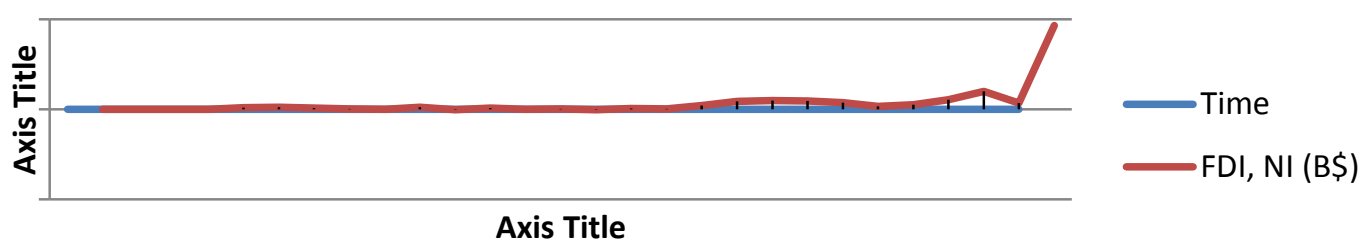

Source: Computed in Excel

The Figure-13, that FDI inflow into Nepal from 1992-2019, i.e. 28 years data have been shown, where one trend line has been computed which shows that the inflow of FDI into Nepal initially is zero up to 1996 but after that from 1997 it has been little bit increased up to 2007 in constant rate. From 1992 to
1995 , it is constantly increasing but in slow rate after 2003 it has been increased then decreased and so on up to 2017. 2017 onwards it is increase in trend. 
Figure-14: The Total FDI Outflow by Nepal from 1992-2019

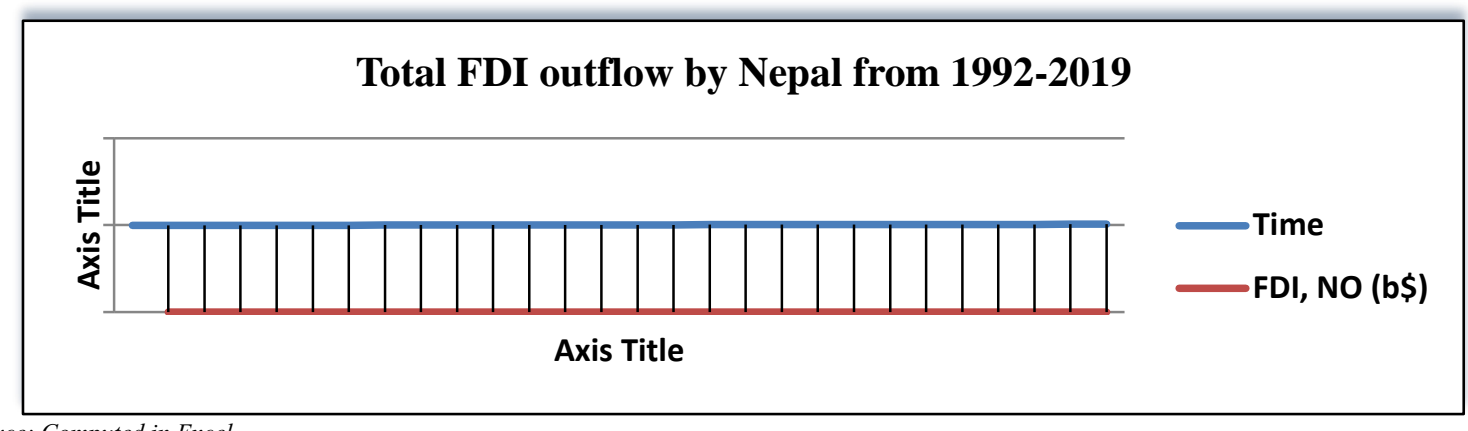

Source: Computed in Excel

The Figure-14, which shows the FDI out flow from Nepal, is not there in any time period. Which clearly shows that no FDI going out from Nepal.

Figure-15: The Net FDI in Nepal from 1992-2019

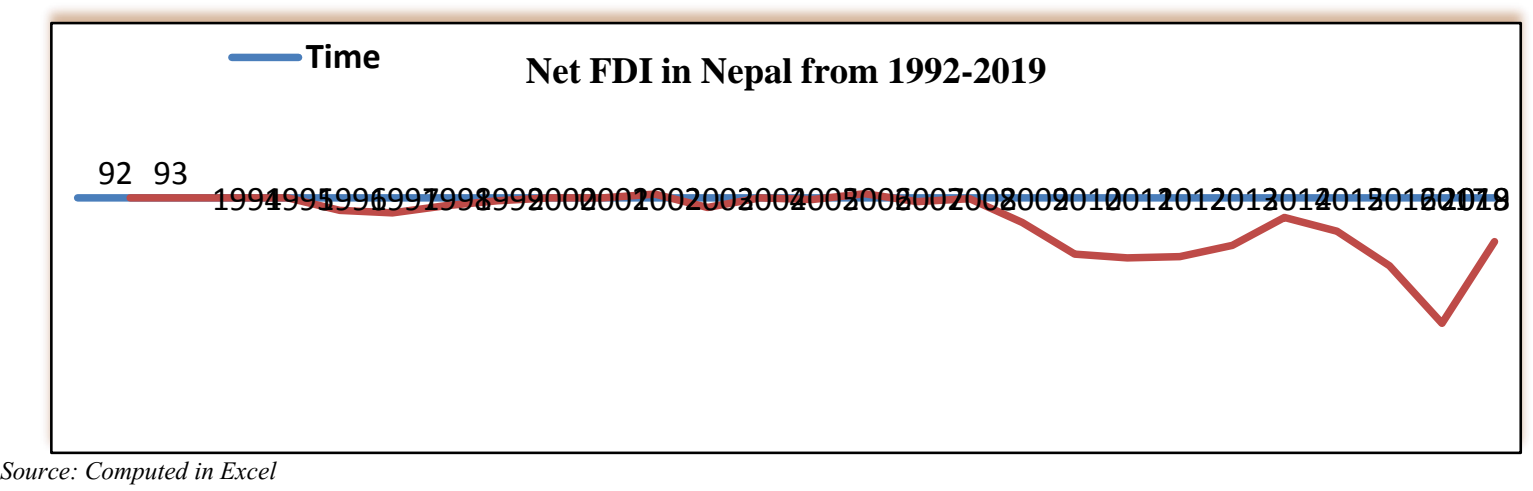

In Figure-15, regarding the net FDI in Nepal, that is totally in negative in trend. In 2017 it is $-196.27 \mathrm{~m}$
USD which is very low. Then is has been increased to $-68.19 \mathrm{~m}$ USD in 2019.

\section{FDI Scenario in All Five South Asian Nations}

Table-6: FDI Inflow into All Five Nations from 1992 to 2019

\begin{tabular}{|c|c|c|c|c|c|}
\hline Time & INDIA & PAKISTAN & SRI LANKA & BANGLADESH & NEPAL \\
\hline NI (m \$) & $\begin{array}{c}\text { FDI, } \\
\text { NI (m \$) }\end{array}$ & $\begin{array}{c}\text { FDI, } \\
\text { NI (m \$) }\end{array}$ & $\begin{array}{c}\text { FDI, } \\
\text { NI (m \$) }\end{array}$ & $\begin{array}{c}\text { FDI, NI } \\
\text { (m \$) }\end{array}$ \\
\hline 1992 & 276.51 & 336.48 & 0.00 & 3.72 & 0.00 \\
\hline 1993 & 550.37 & 348.56 & 122.63 & 14.05 & 0.00 \\
\hline 1994 & 973.27 & 421.02 & 194.48 & 11.15 & 0.00 \\
\hline 1995 & 2143.63 & 722.63 & 166.41 & 1.90 & 0.00 \\
\hline 1996 & 2426.06 & 921.98 & 56.00 & 13.53 & 0.00 \\
\hline 1997 & 3577.33 & 716.25 & 119.87 & 139.38 & 19.16 \\
\hline 1998 & 2634.65 & 506.00 & 430.06 & 190.06 & 23.06 \\
\hline 1999 & 2168.59 & 532.00 & 193.42 & 179.60 & 12.02 \\
\hline 2000 & 3584.22 & 308.00 & 176.41 & 280.38 & 4.35 \\
\hline 2001 & 5128.09 & 378.00 & 172.94 & 78.53 & -0.48 \\
\hline 2002 & 5208.97 & 826.00 & 171.79 & 52.30 & 20.85 \\
\hline 2003 & 3681.98 & 534.00 & 196.50 & 268.29 & -5.95 \\
\hline 2004 & 5429.25 & 1118.00 & 228.72 & 448.91 & 14.78 \\
\hline 2005 & 7269.41 & 2201.00 & 232.80 & 813.32 & -0.42 \\
\hline 2006 & 20029.12 & 4273.00 & 272.40 & 456.52 & 2.45 \\
\hline 2007 & 25227.74 & 5590.00 & 479.70 & 651.03 & -6.65 \\
\hline 2008 & 43406.28 & 5438.00 & 603.00 & 1328.42 & 5.74 \\
\hline
\end{tabular}


ISSN (Online): 2455-3662

EPRA International Journal of Multidisciplinary Research (IJMR) - Peer Reviewed Journal

Volume: 7 | Issue: 4 | April 2021|| Journal DOI: 10.36713/epra2013 || SJIF Impact Factor 2021: 8.047 || ISI Value: 1.188

\begin{tabular}{|c|c|c|c|c|c|}
\hline 2009 & 35581.37 & 2338.00 & 752.20 & 901.29 & 1.00 \\
\hline 2010 & 27396.89 & 2022.00 & 404.00 & 1232.26 & 38.27 \\
\hline 2011 & 36498.65 & 1326.00 & 477.56 & 1264.73 & 87.74 \\
\hline 2012 & 23995.69 & 859.00 & 955.92 & 1584.40 & 94.02 \\
\hline 2013 & 28153.03 & 1333.00 & 941.12 & 2602.96 & 91.95 \\
\hline 2014 & 34576.64 & 1887.00 & 932.55 & 2539.19 & 74.18 \\
\hline 2015 & 44009.49 & 1673.00 & 893.63 & 2831.15 & 30.40 \\
\hline 2016 & 44458.57 & 2576.00 & 679.66 & 2332.72 & 51.90 \\
\hline 2017 & 39966.09 & 2496.00 & 897.05 & 1810.40 & 106.00 \\
\hline 2018 & 42117.45 & 1737.00 & 1372.72 & 2940.22 & 196.27 \\
\hline 2019 & 50605.33 & 2218.00 & 1610.54 & 1596.75 & 68.19 \\
\hline Total & 541074.68 & 45635.92 & 13734.08 & 26567.17 & 928.82 \\
\hline
\end{tabular}

Source: World Bank Database

In above table, that is table-6, in which the data regarding FDI inflow into all five nations separately from 1992-2019, have been shown, where the total FDI inflow into all five South Asian nations is
$541074.68 \mathrm{~m}$ USD in India, $45635.92 \mathrm{~m}$ USDin Pakistan, 13734.08 mUSD in Sri Lanka, $26567.17 \mathrm{~m}$ USD in Bangladesh, $928.82 \mathrm{~m}$ USD in Nepal during this 28 years time period.

Figure-16: The Total FDI Inflow into All Five Nations from 1992-2019

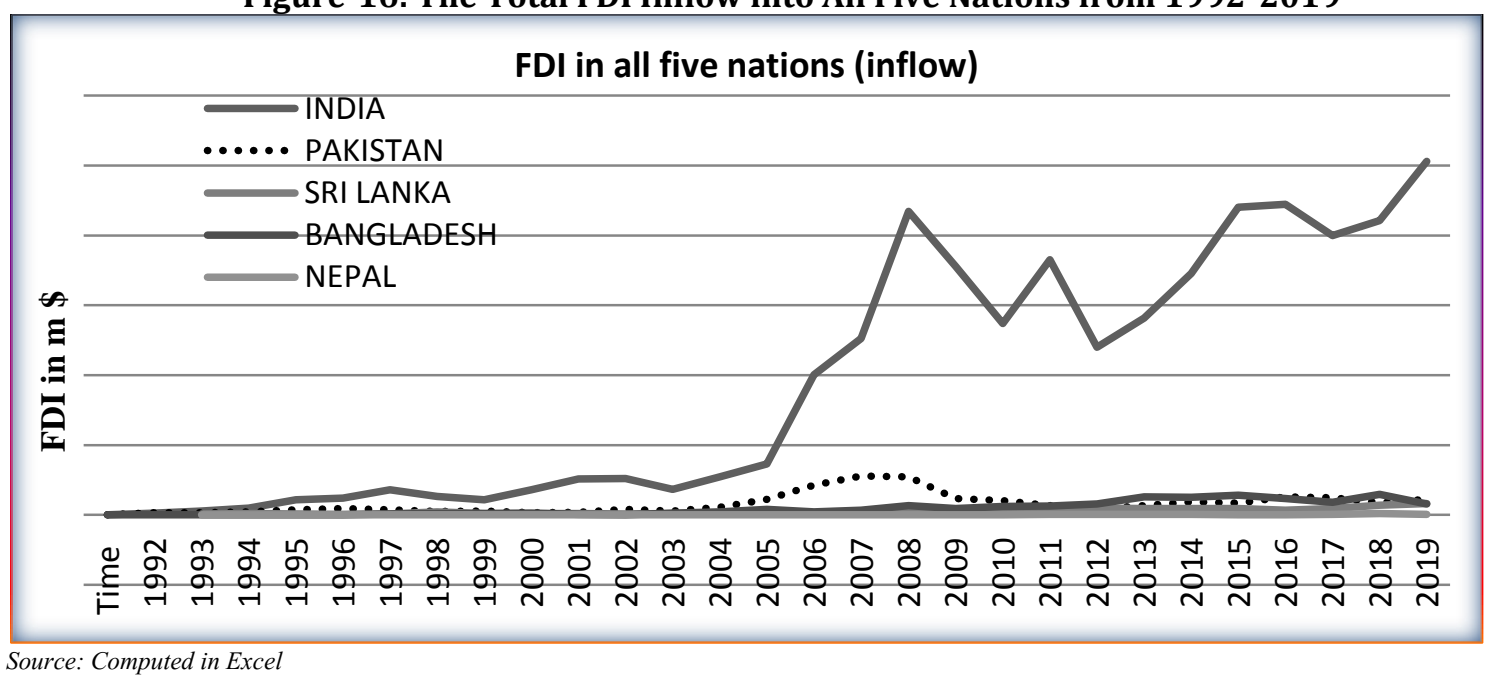

In above figure, that is Figure-16, in which the data regarding FDI inflow into all five nations separately from 1992-2019, have been shown, where the total FDI inflow into all five South Asian nations is increasing but comparatively India is in better position that the black colour is for India which indicates in increasing in trend line than other four countries.

Table -7: Percentage wise FDI Inflow into All Five Nations from 1992 to 2019

\begin{tabular}{|c|c|c|c|c|c|c|c|}
\hline \multirow[t]{2}{*}{ Time } & \multirow{2}{*}{$\begin{array}{l}\text { Total FDI of } \\
\text { all in year } \\
\text { wise }\end{array}$} & INDIA & PAK & SRL & BAN & NEPAL & \multirow[t]{2}{*}{ Ratio } \\
\hline & & \multicolumn{5}{|c|}{$\%$ of FDI } & \\
\hline 1992 & 616.71 & 45 & 55 & 0 & 1 & 0 & $22: 27: 0: 0: 0$ \\
\hline 1993 & 1035.61 & 53 & 34 & 12 & 1 & 0 & $53: 34: 12: 1: 0$ \\
\hline 1994 & 1599.92 & 61 & 26 & 12 & 1 & 0 & $30: 13: 6: 0: 0$ \\
\hline 1995 & 3034.57 & 71 & 24 & 5 & 0 & 0 & $71: 24: 5: 0: 0$ \\
\hline 1996 & 3417.57 & 71 & 27 & 2 & 0 & 0 & $71: 27: 2: 0: 0$ \\
\hline 1997 & 4552.83 & 79 & 16 & 3 & 3 & 0 & $79: 16: 3: 3: 0$ \\
\hline 1998 & 3760.77 & 70 & 13 & 11 & 5 & 1 & $70: 13: 11: 5: 0$ \\
\hline 1999 & 3073.61 & 71 & 17 & 6 & 6 & 0 & $71: 17: 6: 6: 0$ \\
\hline
\end{tabular}


EPRA International Journal of Multidisciplinary Research (IJMR) - Peer Reviewed Journal Volume: 7 | Issue: 4 | April 2021|| Journal DOI: 10.36713/epra2013 || SJIF Impact Factor 2021: 8.047 || ISI Value: 1.188

\begin{tabular}{|c|c|c|c|c|c|c|c|}
\hline $\mathbf{2 0 0 0}$ & 4349.01 & 82 & 7 & 4 & 6 & 0 & $82: 7: 4: 6: 0$ \\
\hline $\mathbf{2 0 0 1}$ & 5757.56 & 89 & 7 & 3 & 1 & 0 & $89: 7: 3: 1: 0$ \\
\hline $\mathbf{2 0 0 2}$ & 6259.06 & 83 & 13 & 3 & 1 & 0 & $83: 13: 3: 1: 0$ \\
\hline $\mathbf{2 0 0 3}$ & 4680.77 & 79 & 11 & 4 & 6 & 0 & $79: 11: 4: 6: 0$ \\
\hline $\mathbf{2 0 0 4}$ & 7224.88 & 75 & 15 & 3 & 6 & 0 & $25: 5: 1: 2: 0$ \\
\hline $\mathbf{2 0 0 5}$ & 10516.53 & 69 & 21 & 2 & 8 & 0 & $69: 21: 2: 8: 0$ \\
\hline $\mathbf{2 0 0 6}$ & 25031.04 & 80 & 17 & 1 & 2 & 0 & $80: 17: 1: 2: 0$ \\
\hline $\mathbf{2 0 0 7}$ & 31948.47 & 79 & 17 & 2 & 2 & 0 & $79: 17: 2: 2: 0$ \\
\hline $\mathbf{2 0 0 8}$ & 50775.7 & 85 & 11 & 1 & 3 & 0 & $85: 11: 1: 3: 0$ \\
\hline $\mathbf{2 0 0 9}$ & 39572.86 & 90 & 6 & 2 & 2 & 0 & $90: 6: 2: 2: 0$ \\
\hline $\mathbf{2 0 1 0}$ & 31055.15 & 88 & 7 & 1 & 4 & 0 & $88: 7: 1: 4: 0$ \\
\hline $\mathbf{2 0 1 1}$ & 39566.94 & 92 & 3 & 1 & 3 & 0 & $92: 3: 1: 3: 0$ \\
\hline $\mathbf{2 0 1 2}$ & 27395.01 & 88 & 3 & 3 & 6 & 0 & $88: 3: 3: 6: 0$ \\
\hline $\mathbf{2 0 1 3}$ & 33030.11 & 85 & 4 & 3 & 8 & 0 & $85: 4: 3: 8: 0$ \\
\hline $\mathbf{2 0 1 4}$ & 39935.38 & 87 & 5 & 2 & 6 & 0 & $43: 2: 1: 3: 0$ \\
\hline $\mathbf{2 0 1 5}$ & 49407.27 & 89 & 3 & 2 & 6 & 0 & $89: 3: 2: 6: 0$ \\
\hline $\mathbf{2 0 1 6}$ & 50046.95 & 89 & 5 & 1 & 5 & 0 & $89: 5: 1: 5: 0$ \\
\hline $\mathbf{2 0 1 7}$ & 45169.54 & 88 & 6 & 2 & 4 & 0 & $88: 6: 2: 4: 0$ \\
\hline $\mathbf{2 0 1 8}$ & 48167.39 & 87 & 4 & 3 & 6 & 0 & $87: 4: 3: 6: 0$ \\
\hline $\mathbf{2 0 1 9}$ & 56030.62 & 90 & 4 & 3 & 3 & 0 & $90: 4: 3: 3: 0$ \\
\hline Total & 627011.85 & 86 & 7 & 2 & 4 & 0 & $86: 7: 2: 4: 0$ \\
\hline
\end{tabular}

Source: Computed in Excel

The table-7 shows the percentage wise FDI inflow into all five nations and in ratio also. In $2^{\text {nd }}$ column, it is mentioned that total FDI of all five nations in year wise, that is in 1992, $616.71 \mathrm{~m}$ USD received by all five nations, out of it Pakistan got maximum 55\% of FDI, where as India got little bit less percentage of FDI that is $45 \%$, Bangladesh got $1 \%$ and Nepal and Sri Lanka got very minute percentage that is around zero. In ratio wise that is 22:27:0:0:0. But after 1993 India got maximum comparative to all four nations. In 2011, India got maximum percentage of FDI, i.e, $92 \%$. In ratio wise that is $92: 3: 1: 3: 0$ which is 31 times of Pakistan and Bangladesh and 92 times so Sri Lanka.

Table -8: Descriptive Statistics FDI Inflow into All Five Nations:

\begin{tabular}{|c|c|c|c|c|c|}
\hline & INDIA & PAKISTAN & SRI LANKA & BANGLADESH & NEPAL \\
\hline Mean & 19324095556.29 & 1629854368.64 & 490502766.86 & 948827347.38 & 33172209.24 \\
\hline $\mathrm{SE}$ & 3337796185.32 & 271738268.45 & 78486361.04 & 185066762.65 & 8983234.68 \\
\hline Median & 13649263246.38 & 1222000000.00 & 338200000.00 & 553776452.88 & 13401372.75 \\
\hline SD & 17661957266.74 & 1437903760.02 & 415310785.26 & 979281259.83 & 47534809.85 \\
\hline Kurtosis & -1.58 & 2.34 & 0.64 & -0.67 & 3.81 \\
\hline Skewness & 0.36 & 1.62 & 1.10 & 0.82 & 1.83 \\
\hline Range & 50328814914.62 & 5282000000.00 & 1610543974.23 & 2938326047.61 & 202913082.47 \\
\hline Minimum & 276512438.97 & 308000000.00 & 0.00 & 1896372.13 & -6647983.90 \\
\hline $\operatorname{Max}^{\mathrm{m}}$ & 50605327353.59 & 5590000000.00 & 1610543974.23 & 2940222419.73 & 196265098.56 \\
\hline Count & 28.00 & 28.00 & 28.00 & 28.00 & 28.00 \\
\hline
\end{tabular}


Table- 8 shows that the descriptive statistics of all five nations regarding FDI inflow. Indeed, skewness measures the degree of asymmetric in a particular series. So for a normal skewness the value is zero. Here the value of India is 0.36 that is little bit normal distribution which is positively skewed and in series of all nations that it is positive skewed. More ever, in a normal distribution, the kurtosis value must be 3 .
So here for India the kurtosis value is -1.58 that indicates the FDI inflow series is fully platikurtic that is the series is having more lower values below the sample means for the particular series because $1.58<3$. So FDI series of India though resembles the normally distributed curve, it is going to be platikurtic. In Nepal it is peaked curve.

Table -9: FDI Outflow by All Five Nations from 1992 to 2019

\begin{tabular}{|c|c|c|c|c|c|}
\hline & INDIA & PAKISTAN & SRI LANKA & BANGLADESH & NEPAL \\
\hline Time & $\begin{array}{c}\text { FDI } \\
0(\mathrm{~m} \$)\end{array}$ & $\begin{array}{c}\text { FDI } \\
0(\mathrm{~m} \$)\end{array}$ & $\begin{array}{c}\text { FDI } \\
0(\mathrm{~m} \$)\end{array}$ & $\begin{array}{c}\text { FDI } \\
0(\mathrm{~m} \$)\end{array}$ & $\begin{array}{c}\text { FDI } \\
0(\mathrm{~m} \$)\end{array}$ \\
\hline 1992 & 24.00 & -11.58 & 0.00 & 0.10 & 0 \\
\hline 1993 & 0.35 & -2.15 & 1.63 & 0.20 & 0 \\
\hline 1994 & 82.58 & 0.97 & 6.90 & 0.20 & 0 \\
\hline 1995 & 117.19 & 0.41 & 8.26 & 1.70 & 0 \\
\hline 1996 & 2393.25 & 6.79 & 5.60 & 12.50 & 0 \\
\hline 1997 & 112.92 & -24.31 & 6.92 & 3.07 & 0 \\
\hline 1998 & 47.59 & 50.00 & 5.00 & 3.00 & 0 \\
\hline 1999 & 79.36 & 21.00 & 13.00 & 0.06 & 0 \\
\hline 2000 & 5095.33 & 11.00 & 24.00 & 2.00 & 0 \\
\hline 2001 & 1054.13 & 26.00 & 2.00 & 20.60 & 0 \\
\hline 2002 & 1261.07 & 31.00 & 0.00 & 2.64 & 0 \\
\hline 2003 & 1237.85 & 19.00 & 11.45 & 2.78 & 0 \\
\hline 2004 & 1837.06 & 56.00 & 27.31 & 4.07 & 0 \\
\hline 2005 & 2640.75 & 45.00 & 5.79 & 1.94 & 0 \\
\hline 2006 & 14036.83 & 109.00 & 38.40 & 3.59 & 0 \\
\hline 2007 & 17026.11 & 98.00 & 29.30 & 134.26 & 0 \\
\hline 2008 & 19256.53 & 49.00 & 55.00 & 190.66 & 0 \\
\hline 2009 & 16095.58 & 71.00 & 61.70 & 180.83 & 0 \\
\hline 2010 & 15968.10 & 47.00 & 20.00 & 66.44 & 0 \\
\hline 2011 & 12607.99 & 62.00 & 42.50 & 297.43 & 0 \\
\hline 2012 & 8553.24 & 77.00 & 60.00 & 289.06 & 0 \\
\hline 2013 & 1764.95 & 212.00 & 63.93 & 546.88 & 0 \\
\hline 2014 & 11686.48 & 122.00 & 65.07 & 41.77 & 0 \\
\hline 2015 & 7514.28 & 25.00 & 66.82 & 59.90 & 0 \\
\hline 2016 & 5047.29 & 52.00 & 52.99 & 40.52 & 0 \\
\hline 2017 & 11090.15 & 52.00 & 236.81 & 126.74 & 0 \\
\hline 2018 & 11417.79 & -21.00 & 71.79 & 15.23 & 0 \\
\hline 2019 & 12100.93 & -7.00 & 67.86 & -1.18 & 0 \\
\hline Total & 180149.69 & 1177.11 & 1050.01 & 2046.99 & 0 \\
\hline
\end{tabular}

In above table, that is table-9, in which the data regarding FDI out flow by all five nations separately from 1992-2019, have been shown, where the total FDI outflow by all five South Asian nations is
$180149.69 \mathrm{~m}$ USD in India, $1177.11 \mathrm{~m}$ USD in Pakistan, 1050.01 m USD in Sri Lanka, $2046.99 \mathrm{~m}$ USD in Bangladesh, nil in Nepal during this 28 years time period. 
Figure-17: The Total FDI Outflow by Five Nations from 1992-2019

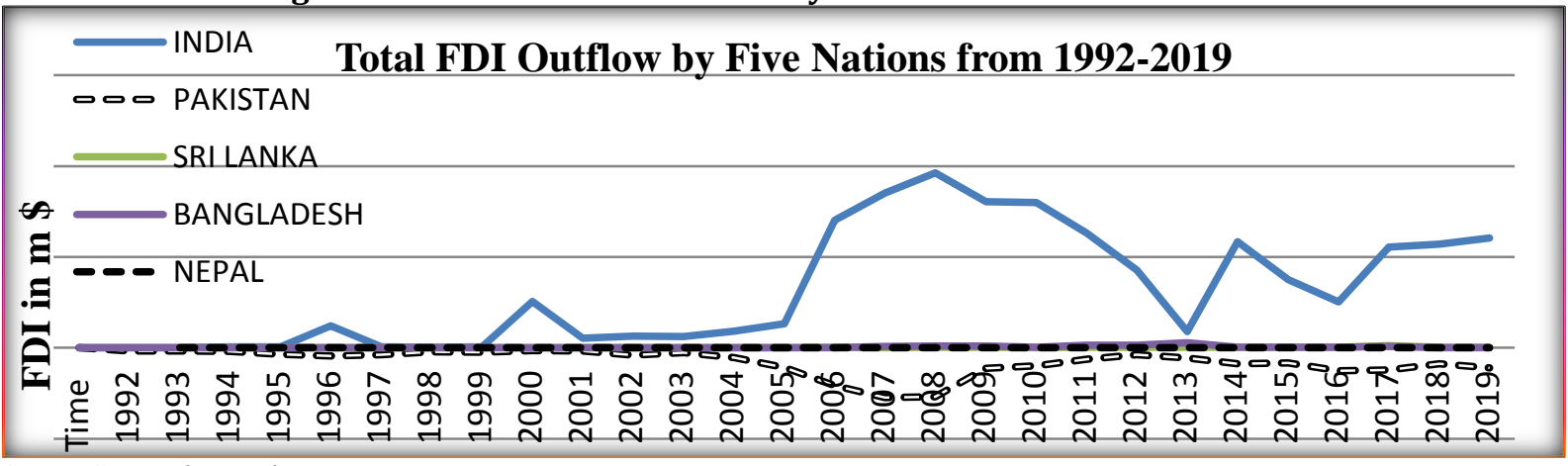

Source: Computed in Excel

In above figure, that is Figure-17, in which the data regarding FDI outflow by all five nations separately from 1992-2019, have been shown, where the total FDI out flow by India is increasing whereas, the out flow by remaining countries except Pakistan is increasing with stable rate. Pakistan goes with negative trend regarding FDI outflow.

Table -10: Descriptive Statistics FDI Outflow by All Five Nations:

\begin{tabular}{|c|c|c|c|c|c|}
\hline & INDIA & PAKISTAN & SRI LANKA & BANGLADESH & NEPAL \\
\hline Mean & 6433917480.16 & 42039809.96 & 37500373.24 & 73106786.40 & 0.00 \\
\hline SE & 1213115588.72 & 9537755.13 & 8827272.48 & 24038795.29 & 0.00 \\
\hline Median & 3844023782.91 & 38000000.00 & 25655000.00 & 8284411.38 & 0.00 \\
\hline SD & 6419204318.67 & 50469056.27 & 46709535.50 & 127201348.29 & 0.00 \\
\hline Kurtosis & -1.20 & 3.55 & 12.15 & 6.50 & 0.00 \\
\hline Skewness & 0.56 & 1.50 & 3.00 & 2.43 & 0.00 \\
\hline Range & 19256176605.54 & 236314471.00 & 236808136.80 & 548060083.77 & 0.00 \\
\hline Minimum & 350640.56 & -24314471.00 & 0.00 & -1183281.16 & 0.00 \\
\hline Maximum & 19256527246.10 & 212000000.00 & 236808136.80 & 546876802.62 & 0.00 \\
\hline Count & 28.00 & 28.00 & 28.00 & 28.00 & 28.00 \\
\hline \multicolumn{7}{|l}{ Source: Computed in Excel }
\end{tabular}

Table-10 shows that the descriptive statistics of all five nations regarding FDI outflow. In India the curve of the series of FDI outflow is little bit normally distributed because the value of kurtosis is less than 3 , whereas peaked curve for other nations except Nepal.

Table-11: Net FDI in All Five Nations from 1992 to 2019

\begin{tabular}{|c|c|c|c|c|c|}
\hline & INDIA & PAK & SRI LANKA & BAN & NEPAL \\
\hline Time & $\begin{array}{l}\text { FDI, N } \\
(\mathrm{m} \$)\end{array}$ & $\begin{array}{l}\text { FDI, N } \\
(\mathrm{m} \text { \$) }\end{array}$ & $\begin{array}{l}\text { FDI, N } \\
(\mathrm{m} \$)\end{array}$ & $\begin{array}{l}\text { FDI, N } \\
(\mathrm{m} \$)\end{array}$ & $\begin{array}{l}\text { FDI, N } \\
(\mathrm{m} \$)\end{array}$ \\
\hline 1992 & -276.51 & -348.06 & 0.00 & -3.72 & 0.00 \\
\hline 1993 & -550.02 & -350.71 & -121.00 & -14.05 & 0.00 \\
\hline 1994 & -890.69 & -420.06 & -187.58 & -11.15 & 0.00 \\
\hline 1995 & -2026.44 & -722.22 & -158.16 & -1.90 & 0.00 \\
\hline 1996 & -2186.73 & -915.19 & -56.00 & -13.53 & 0.00 \\
\hline 1997 & -3464.41 & -740.57 & -119.87 & -136.31 & -19.16 \\
\hline 1998 & -2587.06 & -456.00 & -430.06 & -187.06 & -23.06 \\
\hline 1999 & -2089.23 & -511.00 & -193.42 & -179.60 & -12.02 \\
\hline 2000 & -3074.68 & -297.00 & -176.41 & -280.38 & -4.35 \\
\hline 2001 & -4073.96 & -352.00 & -172.94 & -78.53 & 0.48 \\
\hline 2002 & -3947.90 & -795.00 & -171.79 & -49.66 & 0.00 \\
\hline 2003 & -2444.14 & 00 & 5 & -265.51 & 5.95 \\
\hline
\end{tabular}


ISSN (Online): 2455-3662

EPRA International Journal of Multidisciplinary Research (IJMR) - Peer Reviewed Journal

Volume: 7 | Issue: 4 | April 2021|| Journal DOI: 10.36713/epra2013 || SJIF Impact Factor 2021: 8.047 || ISI Value: 1.188

\begin{tabular}{|c|c|c|c|c|c|}
\hline 2004 & -3592.19 & -1062.00 & -201.41 & -444.84 & -14.78 \\
\hline 2005 & -4628.65 & -2156.00 & -227.01 & -811.38 & 0.42 \\
\hline 2006 & -5992.29 & -4164.00 & -234.00 & -452.93 & -2.45 \\
\hline 2007 & -8201.63 & -5492.00 & -450.40 & -516.77 & 6.65 \\
\hline 2008 & -24149.75 & -5389.00 & -548.00 & -1137.76 & -5.74 \\
\hline 2009 & -19485.79 & -2267.00 & -690.50 & -720.46 & -1.00 \\
\hline 2010 & -11428.79 & -1975.00 & -384.00 & -1165.82 & -38.27 \\
\hline 2011 & -23890.66 & -1264.00 & -435.06 & -967.29 & -87.74 \\
\hline 2012 & -15442.45 & -782.00 & -895.92 & -1295.34 & -94.02 \\
\hline 2013 & -26388.08 & -1121.00 & -877.19 & -2056.09 & -91.95 \\
\hline 2014 & -22890.16 & -1765.00 & -867.48 & -2497.42 & -74.18 \\
\hline 2015 & -36495.22 & -1648.00 & -826.81 & -2771.25 & -30.40 \\
\hline 2016 & -39411.28 & -2524.00 & -626.67 & -2292.21 & -51.90 \\
\hline 2017 & -28875.94 & -2444.00 & -660.24 & -1683.65 & -106.00 \\
\hline 2018 & -30699.66 & -1758.00 & -1300.93 & -2925.00 & -196.27 \\
\hline 2019 & -38504.40 & -2225.00 & -1542.69 & -1597.94 & -68.19 \\
\hline Total & -367688.71 & -44458.81 & -12740.58 & -24557.54 & -907.97 \\
\hline
\end{tabular}

Source: World Bank Database

In above table, that is table-11, in which the data regarding net FDI in all five nations separately from 1992-2019, have been shown, where the total net FDI in all five South Asian nations is $-367688.71 \mathrm{~m}$ USD in India, -44458.81 m USD in Pakistan, -12740.58 m USD in Sri Lanka, -24557.54 m USD in Bangladesh, $-907.97 \mathrm{~m}$ in Nepal during this 28 years time period.

Figure-18: The Net FDI Inflow into All Five Nations from 1992-2019 Net FDI Inflow into All Five Nations from 1992-2019

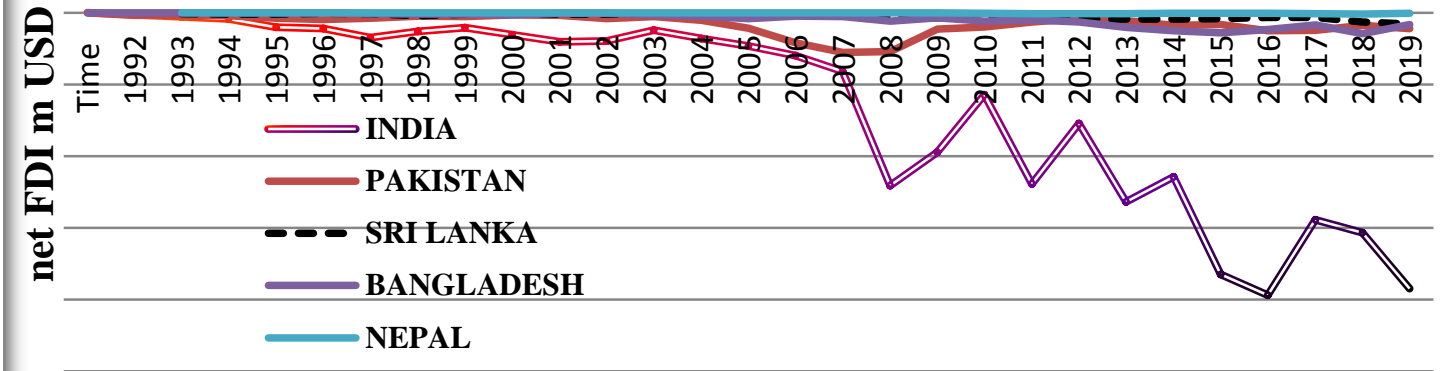

Source: Computed in Excel

In above figure, that is chart-18, in which the data regarding net FDI in all five nations separately from
1992-2019, have been shown, where the total net FDI India is decreasing compare to other nations.

Table-12: Descriptive Statistics Net FDI in All Five Nations:

\begin{tabular}{|c|c|c|c|c|c|}
\hline & INDIA & PAKISTAN & SRI LANKA & BANGLADESH & NEPAL \\
\hline Mean & -13131739473.61 & -1587814558.64 & -455020842.22 & -877054845.40 & -32427566.38 \\
\hline SE & 2481922930.69 & 268137200.10 & 72875606.39 & 175038945.98 & 9051667.01 \\
\hline Median & -5310469100.42 & -1091500000.00 & -309000000.00 & -484847290.31 & -8883182.98 \\
\hline SD & 13133101695.65 & 1418848697.40 & 385621462.29 & 926219041.64 & 47896919.72 \\
\hline Kurtosis & -0.86 & 2.40 & 1.19 & -0.29 & 3.74 \\
\hline Skewness & -0.79 & -1.64 & -1.24 & -0.96 & -1.83 \\
\hline Range & 39134766501.28 & 5195000000.00 & 1542687403.69 & 2923100705.87 & 202913082.47 \\
\hline Minimum & -39411278940.25 & -5492000000.00 & -1542687403.69 & -2924997078.00 & -196265098.56 \\
\hline Maximum & -276512438.97 & -297000000.00 & 0.00 & -1896372.13 & 6647983.90 \\
\hline Count & 28.00 & 28.00 & 28.00 & 28.00 & 28.00 \\
\hline
\end{tabular}

Source: Computed in Excel 
Table-12 shows that the descriptive statistics of all five nations regarding net FDI. In this series for India the kurtosis value is less than 3 along with all nations excerpt Nepal. That shows the series of all nations getting normal distribution excerpt Nepal.

\section{Significance of the Study}

In order to remove constraints and foster growth, the FDI Policy proposes relaxing rules for important sectors. India has moved to a more liberalized FDI regime over the past few years which include allowing FDI to enter through the automatic route in most cases, and raising FDI cap for many sectors. The Government of India has put in place a liberal and transparent policy for investment from overseas Indians. Most of the sectors are open to FDI under the automatic route. FDI policy provides incentive schemes for foreign investors,

\section{RESULTS AND DISCUSSION}

In this paper FDI inflows and FDI outflows have been studied. It is suggested thatSouth Asian countries need to improve their domestic investment, exports and infrastructure facilities, along with more foreign investment, to achieve higher growth. This report analysis of FDI flows to south Asian countries reveals that there has been an increasing trend of FDI into South Asian countries. FDI has a positive impact on export growth through its positive spillovers for South Asian countries FDI in South Asia is mostly concentrated in manufacturing and services. Despite some policies reforms, Bangladesh could not attract handsome flow of FDI yet. Furthermore, the lion's share of FDI is being repatriated.

\section{CONCLUSION}

The common consensus regarding Foreign Direct Investment (FDI) is it played vital role in ameliorating the economies of developing countries. Hence, policy makers of the developing countries are quite interested to know about the factors that have huge influences on FDI flows. Actually, there are so many factors that have influence on FDI flows directly or indirectly. This study considered a panel of the five South Asian countries: India, Pakistan, and Sri Lanka, Bangladesh and Nepal, for the period from 1992 to 2019. Considering this, policy makers of the South Asian countries should take initiatives to increase the size of their own market to attract more and more FDI as it is considered as an influential tool of economic development and growth.

\section{REFERENCES}

1. Dugal, A. (2017). Foreign Direct Investment in India. December 2017, Vol. 22, No. 3

2. Bilali, J. \& Choong, A.C. (2017). Foreign Direct Investment and Public Sector Management and Institutions: The Acquaintances in Sub-Saharan Africa (SSA) Low-Income Economies. African
Journal of Economic Review, Volume V, Issue Ii, July 2017

3. Gupta, V. (2017). Exploring the Relation between Human Capital and Foreign Direct Investment Indian Context. The Journal of Industrial Statistics (2017), 6(1).

4. Yilmaz, B.A. \& Naib (2016). Corruption and Foreign Direct Investment Inflows in Emerging Market Economies. Volume 5, Issue 2 (9), 2016.

5. Sharma, M. \& Satinderpal, S. (2016). Impact of FDI on Indian Economy. ISBN 2278 - 0211, and Vol 5.

6. Elangbam, B. (2016). An Overview on Foreign Direct Investment in India. Volume 6, Issue 4.

7. Babu, G.S. \&. Sekhar, M. R. (2015). Impact of Foreign Direct Investment (FDI) In Indian Food Processing Sector. Volume 17.

8. Muhammad, A, Saleem, K, Zalina, B. Z, Namasivayam, K. \& Farah. K. (2015). Foreign Direct Investment and Human Capital: Evidence from Developing Countries. Investment Management and Financial Innovations, 12(3-1), 155-162, Investment Management and Financial Innovations.

9. Rajeswaricx, G. R. \& Akilandeswari, K. (2015). Sector-Wise Foreign Direct Investment Inflows into India. Journal of Business Management \& Social Sciences Research (JBM \&SSR).

10. Haque, M. S. (2016). Foreign Investment in Bangladesh: A Distant Reality. Journal of Finance and Banking 1.2 (December 1991). 